Faculty Scholarship

2010

\title{
Beyond Cardboard Clients in Legal Ethics
}

Kate Kruse

Mitchell Hamline School of Law, kate.kruse@mitchellhamline.edu

Publication Information

23 Georgetown Journal of Legal Ethics 103 (2010)

Reprinted with permission of the publisher, Georgetown Journal of Legal Ethics (C2010

\section{Repository Citation}

Kruse, Kate, "Beyond Cardboard Clients in Legal Ethics" (2010). Faculty Scholarship. Paper 321.

http://open.mitchellhamline.edu/facsch/321

This Article is brought to you for free and open access by Mitchell Hamline 


\title{
Beyond Cardboard Clients in Legal Ethics
}

\begin{abstract}
This Article argues that the construction of cardboard clients in legal ethics has disserved legal ethics by obscuring what is arguably a more central problem of legal professionalism: the problem of legal objectification. The problem of legal objectification is the tendency of lawyers to "issue-spot" their clients as they would the facts on a blue-book exam, overemphasizing the clients' legal interests and minimizing or ignoring the other cares, commitments, relationships, reputations and values that constitute the objectives clients bring to legal representation. This Article proposes an alternative ideal of legal professionalism for "three-dimensional clients" based on helping clients articulate and actualize their values through the law. It argues that a client value-based model of representation survives the critiques of early legal ethicists and provides an antidote against both the self-seeking behavior that legal objectification promotes and the danger of moral overreaching associated with the lawyer-statesman model.
\end{abstract}

\section{Keywords}

Attorney and client, Legal ethics

\section{Disciplines}

Legal Ethics and Professional Responsibility 


\title{
Beyond Cardboard Clients in Legal Ethics
}

\author{
KATHERINE R. KRUSE*
}

\begin{abstract}
Historically, legal ethics scholars preoccupied themselves with the moral conflicts that arise when the pursuit of a client's interests requires a lawyer to harm innocent third parties, undermine the truth-seeking norms of the legal system, or both. But is over-zealous loyalty to clients really the most important issue that plagues legal professionalism? This Article argues that it is not. Rather, the obsession in legal ethics with the problems of zealous partisanship dates back to a preference of early legal ethics scholars, most of whom were philosophers, to focus on conflicts between professional role morality and ordinary morality. To generate these conflicts, legal ethics scholars had to construct clients as "cardboard clients"- one dimensional figures interested only in maximizing their legal and financial interests. Implicit assumptions about cardboard clients also led these ethicists to propose the problematic solution that lawyers should act as moral consciences for their clients. The "lawyer-statesman" model that emerged as an alternative professional ideal rests on the morally elitist assumption that lawyers are better situated than clients to exercise moral judgment and carries the danger of moral overreaching when lawyers and clients disagree about morality.

This Article argues that the construction of such cardboard clients for the purpose of studying legal ethics disserves legal ethics by obscuring what is arguably a more central problem of legal professionalism: the problem of legal objectification. The problem of legal objectification is the tendency of lawyers to "issue-spot" their clients as they would the facts on a blue book exam, overemphasizing the clients' legal interests and minimizing or ignoring the other cares, commitments, relationships, reputations, and values that constitute the objectives clients bring to legal representation. This Article proposes an alternative ideal of legal professionalism for "three-dimensional clients" based on helping clients articulate and actualize their values through the law. This Article argues that a client value-based model of representation survives the
\end{abstract}

\footnotetext{
* Professor of Law, William S. Boyd School of Law, University of Nevada, Las Vegas. The following persons merit special thanks for facilitating invaluable discussion of these ideas and feedback on earlier drafts this article: Annette Appell, Susan Carle, David Luban, Russell Pearce, Nancy Rapoport, and Ted Schneyer. This article benefited greatly from presentation at the Law Speakers Series at American University, Washington College of Law, the Clinical Research Forum at William S. Boyd School of Law, and the Potomac Valley Writers' Workshop.
} 
critiques of early legal ethics scholars and provides an antidote against both the self-seeking behavior that legal objectification promotes and the danger of moral overreaching associated with the lawyer-statesman model.

In the world of legal ethics, clients are most often constructed as cardboard figures interested solely in maximizing their own wealth or freedom at the expense of others. ${ }^{1}$ Scour any professional responsibility textbook and you will find examples of the ethical issues that arise when the pursuit of a client's interests requires a lawyer to harm innocent third parties, undermine the truth-seeking norms of the legal system, or both. The proliferation of these examples is no accident. Rather, they arose as a consequence of a choice by early legal ethicists to focus on the dilemma faced by a lawyer forced by professional duty to do something that would otherwise be wrong. To generate this kind of dilemma, legal ethics scholars had to posit hypothetical clients impervious to ordinary moral considerations, unconcerned with preserving their relationships with others and indifferent to their reputations in the community.

This Article argues that the reliance on "cardboard clients"-one dimensional figures who are only concerned with maximizing their legal and financial interests-disserves legal ethics by obscuring important issues of professional responsibility that cannot be examined in the simplified world of the standard professional responsibility hypothetical. Most notably, the reliance on cardboard clients has disabled legal ethicists from confronting a problem I call "legal objectification." "Legal objectification" is the tendency of lawyers to view their clients as walking bundles of legal rights and interests rather than as whole persons whose legal issues often come deeply intertwined with other concernsrelationships, loyalties, hopes, uncertainties, fears, doubts, and values-that shape the objectives they bring to legal representation.

The classic case of Spaulding v. Zimmerman can be used to illustrate the problem of relying on cardboard clients to explore the ethical obligations of lawyers. ${ }^{2}$ In Spaulding, the personal injury lawyer for the defense learned from his own medical expert that the plaintiff suffered a heart aneurysm probably caused by the automobile accident at issue in the case. ${ }^{3}$ The defense lawyer proceeded to settle the case without ever revealing to the plaintiff that his life was in danger. ${ }^{4}$ The court reopened the settlement two years later when the aneurysm was discovered in a routine medical examination. ${ }^{5}$ The court, however, noted in

1. See Ann Shalleck, Constructions of the Client Within Legal Education, 45 STAN. L. REv. 1731, 1737 (1993); Robert Rubinson, Attorney Fàct-Finding, Ethical Decision-Making and the Methodology of Law, 45 ST. Louis U. L.J. 1185, 1212 (2001).

2. Spaulding v. Zimmerman, 116 N.W.2d 704 (Minn. 1962); see also Timothy W. Floyd \& John Gallagher, Legal Ethics, Narrative and Professional ldentity: The Story of David Spaulding, 59 MERCER L. REv. 941 955-57 (2008).

3. Id. at 707.

4. Id. at 708 .

5. Id. at 708 . 
dicta that "no canon of ethics or legal obligation" required the defense lawyer to inform the plaintiff of the life-threatening medical condition. ${ }^{6}$

For almost thirty years, legal ethics scholars have used the dramatic facts of Spaulding to discuss the boundaries of a lawyer's competing moral and professional duties when divulging confidential information that could save a human life. ${ }^{7}$ To use Spaulding to explore this moral and ethical dilemma, however, one must imagine a client who will not consent to disclose the confidential information. Lawyers are always ethically permitted to reveal confidential information if the client consents after consultation. ${ }^{8}$ If the client in Spaulding consented to reveal the information, perhaps because the client shares the lawyer's concern for the value of human life, the lawyer's dilemma would have disappeared.

Upon further examination, the facts behind Spaulding suggest that the client would have consented to reveal the potentially life-saving information, if his lawyer had consulted him. ${ }^{9}$ The litigation in Spaulding arose from a car accident in the mid-1950s involving three families living in the same rural area of Minnesota. ${ }^{10}$ The action was brought on behalf of 20-year-old David Spaulding, a passenger in the car driven by 19-year-old John Zimmerman. ${ }^{11}$ When the accident occurred, Zimmerman was transporting Spaulding and other employees of his father's road construction business home from a worksite at dusk. Their car collided with a car occupied by the Ledermann family on their way to the county fair. ${ }^{12}$ The accident was a tragic event for all three families. In addition to seriously injuring David Spaulding, the accident killed 12-year-old Elaine Ledermann, who was thrown from her car, killed John Zimmerman's brother James, also a passenger in his car, and broke the neck of John Zimmerman's father, Edward. ${ }^{13}$ Given the close relationship between John Zimmerman and David Spaulding and the devastating loss his own family had already suffered, Zimmerman likely would have consented-even wanted-to reveal medical

6. Id. at 710 .

7. See Roger C. Cramton \& Lori P. Knowles, Professional Secrecy and Its Exceptions: Spaulding v. Zimmerman Revisited, 83 MINN. L. REv. 63, 65-66, 72 (1998). For many years, the public policy exception to permit disclosure to prevent harm to others was conditioned on "prevent[ing] the client from committing a criminal act that was reasonably certain to cause imminent death or substantial bodily harm." MODEL RULES OF PROF'L CONDUCT R. 1.6(b)(1) (1983) (emphasis added). The most recent amendments to the ABA Model Rules omit the requirement that one's client be criminally culpable and permit disclosure "to prevent reasonably certain death or substantial bodily harm" regardless of whether the threat to life or bodily security arises from a criminal act. MOdel Rules of PROF'L CONDUCT R. 1.6(b)(1) (2007) [hereinafter MODEL RULES].

8. See Model Rules R. 1.6(a) ("A lawyer shall not reveal information relating to the representation of a client unless the client consents after consultation, except for disclosures that are impliedly authorized in order to carry out the representation, and except as stated in paragraph (b).") (emphasis added).

9. Cramton \& Knowles, supra note 7, at 94.

10. Id. at 63-64.

11. Spaulding v. Zimmerman, 116 N.W.2d 704, 706-07 (Minn. 1962).

12. Cramton \& Knowles, supra note 7 , at 63 .

13. Id. at 64 . 
information critically important to Spaulding's health and life. ${ }^{14}$

The more interesting moral and ethical question revealed by the facts in Spaulding is why a lawyer would make the decision not to reveal the confidential information without even consulting his client. One likely answer is that the lawyer in Spaulding saw his job as simply to maximize his client's legal and financial interests and did not consider the effect of the settlement on the client's other values or relationships. ${ }^{15}$ In other words, the lawyer in Spaulding possibly succumbed to legally objectifying his client, viewing John Zimmerman narrowly as nothing more than a collection of legal and financial interests disconnected from the rest of his life.

Legal ethics scholars have not generally explored the problem of legal objectification revealed in Spaulding, nor could they. To create the dilemma legal ethics scholars wanted to discuss, John Zimmerman had to be constructed as a cardboard figure unwilling to reveal confidential information that might increase the damages for which he was liable. Once Zimmerman is constructed as a cardboard figure, it is no longer possible to see-much less to confront-the problem of legal objectification also raised by the case. Such oversight will always occur when legal ethicists rely on cardboard clients because cardboard clients are constructed in theory from the very same narrowing assumptions that create the problem of legal objectification in practice.

The construction of cardboard clients in legal ethics has other theoretical costs. Relying on the image of cardboard clients, legal ethics scholars have exaggerated the problem of over-zealous partisanship and proposed solutions that distort the balance between lawyers' professional obligations to clients and their obligations to the public. The alternative professional ideal most commonly proposed by legal ethicists, sometimes called the "lawyer-statesman model," exhorts lawyers to conform their clients' objectives to the public good even if that means manipulating or betraying their clients in the process. ${ }^{16}$ Yet, reasonable persons often disagree about the content and application of moral standards. Lawyers who judge their clients' objectives based on moral standards that the clients do not share can become guilty of moral overreaching. The image of the moral lawyer responsible for enforcing the public good enables a systemic denial of the reality-glaringly obvious to non-lawyer observers-that lawyers often pursue their own self-interest at the expense of their clients. ${ }^{17}$

This Article seeks to move legal ethics beyond cardboard clients by re-

14. See id. at 94 . The authors based this conclusion in part on interviews with surviving members of the Zimmerman and Ledermann families. Id. at 91-92; see also Floyd \& Gallagher, supra note 2, at 947 (describing how the Lederman and Zimmerman families had little contact or consultation with the lawyers hired by the insurance companies to represent them).

15. Cramton \& Knowles, supra note 7, at 94-96; Floyd \& Gallagher, supra note 2, at 954.

16. See infra Part II.C.

17. See infra Part III.E. 
imagining how the ideals of professionalism could have developed if legal ethics scholars had diagnosed the problem of legal objectification and sought to cure it. Part I examines the theoretical history of legal ethics at the time of its post-Watergate fluorescence, showing how the assumptions of moral lawyers and cardboard clients arose from the way legal ethics scholars initially framed the interesting issues in legal ethics as conflicts between ordinary morality and role morality. Part II re-examines the theoretical history of legal ethics to reveal an early interest in the problem of legal objectification that was never fully explored and shows how contemporaneous movements in legal interviewing and counseling literature implicitly addressed the problem of legal objectification. Part III proposes a model of partisanship for three-dimensional clients that brings these divergent strands together and places fidelity to client values at the center of a lawyer's partisan duties. Part IV examines the limitations of the client valuebased model of representation proposed in Part III in the contexts of representing diminished capacity clients, representing organizational clients, and pursuing cause lawyering where mobilization around collective values is necessary to fight systemic injustice.

\section{Moral Lawyers and Cardboard Clients in Legal Ethics}

Theoretical interest in legal ethics experienced a fluorescence in the mid1970 s, and it was a propitious time for theoretical development in the field. ${ }^{18}$ Monroe Freedman was in the midst of a searing campaign to unseat the orthodoxy and hypocrisy of professional self-regulation. ${ }^{19}$ The American Bar Association ("ABA") adopted a law school accreditation standard that required instruction in professional responsibility. ${ }^{20}$ Furthermore, the legal profession was itself undergoing intense self-scrutiny. The ABA was beginning an open, public, and at times hotly-contested process of re-writing the standards that govern professional regulation into the Model Rules of Professional Conduct. ${ }^{21}$ The

18. Although I refer to the scholars of this time as the "early legal ethics scholars," I do not mean to suggest that they were the first generation of scholars to consider legal ethics. The first American scholars to give thoughtful attention to the ethical obligations of lawyers were Nineteenth Century thinkers David Hoffman and George Sharswood. See Russell G. Pearce, Lawyers as America's Governing Class: The Formation and Dissolution of the Original Understanding of the Lawyer's Role, 8 U. CH. L. ScH. RoundTABLE 381, 388-90 (2001). However, I refer to the scholars of the 1970 s as the "early legal ethics scholars" because it was their scholarship that entrenched legal ethics as a field of legal scholarship within the legal academy.

19. Monroe H. Freedman, Professional Responsibility of the Criminal Defense Lawyer: The Three Hardest Questions, 64 Mich. L. Rev. 1469, 1469, n.1 (1966); Monroe H. Freedman, LaWyers' Ethics IN AN ADVERSARY SYSTEM vii-viii (1975); see also William H. Simon, "Thinking Like a Lawyer" About Legal Ethics, 27 HofSTRA L. REv. 1, 1 (1998) (describing the impact of Freedman's work).

20. David Luban, Calming the Hearse Horse: A Philosophical Research Program for Legal Ethics, $40 \mathrm{MD}$. L. Rev. 451, 452-53 (1981); David Luban, Reason and Passion in Legal Ethics, 51 STAN. L. Rev. 873, 878-79 (1999).

21. In 1969, the ABA replaced the 1908 Canons of Professional Ethics with the Code of Professional Responsibility. In 1977, the ABA appointed a Commission on the Evaluation of Professional Standards chaired 
Kutak Commission, which took on the task of drafting the Model Rules, was conscious of the need to rehabilitate the public image of lawyers and was deliberately solicitous of academic critique as a source of guidance in the early stages of its rule-making process. ${ }^{22}$

The initial foray by moral philosophers into legal ethics was launched by philosopher Richard Wasserstrom's 1975 essay, Lawyers as Professionals: Some Moral Issues. ${ }^{23}$ In the decade or so that followed, a host of moral philosophers and legal scholars weighed in on the theoretical questions of how to justify lawyers' professional behavior. ${ }^{24}$ Looking back on the earliest moral philosophical essays in legal ethics, David Luban commented that the early scholars "inaugurated a new approach to legal ethics ... that centers on the issue of role morality and its conflict with universal morality." ${ }^{25}$ As Part II of this Article will demonstrate, however, the conflict between professional role morality and universal morality was not the only way that the important moral questions in legal practice could have been framed. Wasserstrom's earliest essay raised a concern-arguably at the center of his critique of legal professionalism-that lawyers tend to objectify their clients in terms of their clients' legal interests, which I am calling the "problem of legal objectification."

This Part will explore how moral theory developed away from Wasserstrom's diagnosis of legal objectification as a central moral problem of legal professionalism and came to rely in theory on the same kind of legal objectification that

by Robert Kutak to recommend revisions to the Code of Professional Responsibility. Between 1977 and 1983 , the Kutak Commission engaged the profession and the public in an unprecedented process of ethical reform, circulating four drafts of its own re-formulation of the Code into the Model Rules of Professional Conduct.

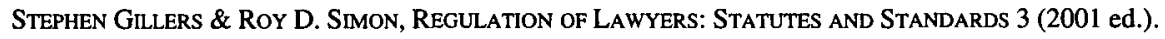

22. See Ted Schneyer, Professionalism as Bar Politics: The Making of the Model Rules of Professional Conduct, 14 LAw \& Soc. INQUTRY 677, 677 (1989).

23. Richard Wasserstrom, Lawyers as Professionals: Some Moral Issues, 5 HuM. RTs. 1 (1975).

24. In 1976, philosopher Charles Fried published a philosophical defense of the morality of the lawyer-client relationship as a "special-purpose friendship." Charles Fried, The Lawyer as Friend: The Moral Foundations of the Lawyer-Client Relation, 85 YALE L.J. 1060 (1976). These two articles set the agenda for further discussion in the field of philosophy. Luban, Reason and Passion, supra note 20, at 878-79. Other early articles included Monroe H. Freedman, Personal Responsibility in a Professional System, 27 CATH. U. L. Rev. 191 (1978); Warren Lehman, The Pursuit of a Client's Interests, 77 MiCH. L. Rev. 1078 (1979); David Luban, Paternalism and the Legal Profession, 1981 WIS. L. Rev. 454; David Luban, The Lysistratian Prerogative: A Response to Stephen Pepper, 1986 AM. B. Found. Res. J. 637; Stephen L. Pepper, The Lawyer's Amoral Ethical Role: A Defense, A Problem, and Some Possibilities, 1986 AM. B. FouND. Res. J. 613; Gerald J. Postema, Moral Responsibility in Professional Ethics, 55 N.Y.U. L. REv. 63 (1980); Ted Schneyer, Moral Philosophy's Standard Misconception of Legal Ethics, 1984 WIS. L. REv. 1529; Murray L. Schwart,. The Professionalism and Accountability of Lawyers, 66 CAL. L. REv. 669, 673 (1978); Thomas L. Shaffer, Christian Theories of Professional Responsibility, 48 S. CAL. L. REv. 721, 722-23 (1975); Thomas Shaffer, The Practice of Law as a Moral Discourse, 55 Notre DAME L. Rev. 231 (1979); William H. Simon, The Ideology of Advocacy, 1978 WIS. L. Rev. 29; William H. Simon, Homo Psychologicus: Notes on a New Legal Formalism, 32 STAN. L. REv. 487 (1980); William H. Simon, Visions of Practice in Legal Thought, 36 STAN. L. REv. 469 (1984); William H. Simon, Ethical Discretion in Lawyering, 101 HARV. L. REV. 1083 (1988); see also essays collected in THE GOOD LAWYER: LAWYERS' ROLES AND LAWYERS' ETHICS (David Luban ed., 1983).

25. Luban, Reason and Passion, supra note 20, at 878-79. 
Wasserstrom condemned in practice: the cardboard construction of clients defined solely by the maximization of their legal interests.

\section{A. ZEAL AT THE MARGIN AS A ROLE MORALITY FOR LAWYERS}

The most important force in defining and solidifying the study of legal ethics as an academic discipline came from the Working Group on Legal Ethics ("Working Group"). ${ }^{26}$ This group of leading moral philosophers, legal scholars, and practitioners met in 1981 and 1982 to present and discuss a series of papers at the University of Maryland's Center for Philosophy and Public Policy ("Center"). ${ }^{27}$ David Luban, then a young research associate at the Center, devised an ambitious research agenda for the Working Group of "hard, unsolved, and mostly unexplored issues in legal ethics that are amenable to treatment by moral philosophy." "28

Much of the research agenda for the Working Group centered on the question of what lawyers should do when their professional duties require them to take or condone actions they would otherwise consider immoral. ${ }^{29}$ The essays resulting from the Working Group's discussions were published in 1984 in an influential edited volume called The Good Lawyer. ${ }^{30}$ The basic premise of this volume was to examine not the nature of lawyers' ethical lapses, but whether "the professional ideal is itself morally worthy." ${ }^{31}$ As philosopher Charles Fried articulated it in an early article, the question was whether "a good lawyer [can] be a good person."32

The philosophers who explored the question of whether a good lawyer could be a good person framed the issue in terms of conflicts between a lawyer's professional "role morality" and the obligations of "ordinary morality." ${ }^{33}$ As defined by moral philosophers, a "role morality" is a set of norms that apply to us in the various social roles we occupy in life-parent, soldier, lawyer-that are

26. The Working Group was built on a foundation laid in 1977 when the Council for Philosophical Studies held an Institute on Law and Ethics. Conversation with David Luban, Professor of Law, Georgetown University Law Center (Washington D.C., Mar. 23, 2007).

27. Preface to THE GoOD LAWYER, supra note 24, at vii. The Working Group included philosophers Richard Wasserstrom, Gerald Postema, and Bernard Williams, who had already contributed to moral theory in legal ethics. See Wasserstrom, Lawyers as Professionals, supra note 23, at 1; Postema, Moral Responsibility, supra note 24, at 63; Bernard Williams, Politics and Moral Character, in WIlliams, Moral Luck: PhILOsophiCal PAPERS 1973-1980 54, 63-66 (1981). It included legal ethics scholars Charles Wolfram and Murray Schwartz. It also included Robert Kutak, who was at that time chairing the ABA commission drafting the Model Rules of Professional Responsibility. See Preface to THE GOOD LAWYER, supra, at viii.

28. Luban, Calming the Hearse Horse, supra note 20, at 452.

29. Id. at 456,462 . The other, less prominent, questions involved the provision of legal services to indigents. Id. at $471-73$.

30. THE GOOD LAWYER, supra note 24.

31. David Luban, Introduction to, in THE GOOD LAWYER, supra note 24, at 1.

32. Fried, supra note 24 , at 1060.

33. Luban, Introduction, supra note 31 , at 1. 
narrower than the norms of ordinary morality that apply to all of us as persons. ${ }^{34}$ What makes the situation of role morality complicated from a philosophical point of view is that even while we are occupying a social role, we are still persons subject to ordinary moral obligations. ${ }^{35}$ The important and interesting question from the perspective of moral philosophy was how to resolve conflicts between what is right for us to do in our professional roles and what is morally right for us to do as persons. ${ }^{36}$

Because moral philosophers sought to frame the important and interesting questions in legal ethics in terms of conflicts between role morality and ordinary morality, their first order of business was to define lawyers' role morality in terms that would create such conflicts. The task of articulating a morally problematic "role morality" for lawyers was accomplished through articulating and critiquing the "standard conception" of the lawyer's role, defined by principles of partisanship and neutrality. ${ }^{37}$ As defined in the early legal ethical writings, the principle of partisanship requires lawyers to maximize their clients' objectives "within, but all the way up to the limits of the law." ${ }^{38}$ The principle of neutrality relieves lawyers of moral responsibility for the harmful effects on others of actions taken in pursuit of their clients' objectives. ${ }^{39}$ Under the standard conception, a lawyer's professional behavior is constrained only by two parameters: the client's objectives and the limits of the law. ${ }^{40}$ Notably, the standard conception does not include independent moral responsibility for furthering the public good or for regarding the rights or interests of individuals who might be harmed by the legal representation. ${ }^{41}$ Under the standard conception, such considerations are not within the lawyer's job description. The responsibility of ensuring that justice emerges from the clash of competing partisan views of the law and facts in a case is placed on the "broader institutional shoulders" of the adversary system itself. ${ }^{42}$ Moral philosophers posited that this combination of partisan loyalty and moral neutrality lay at the root of the

34. See Richard Wasserstrom, Roles and Morality, in THE GOOD LAWYER, supra note 24, at 25; DAVID Luban, Lawyers and Justice: An Ethical Study 104-27 (1988). But see Bemard Williams, Professional Morality and Its Dispositions, in THE GOOD LAWYER, supra note 24, at 259, 259-62 (arguing that it is more helpful and less misleading to consider such conflicts in terms of the dispositions that professionals acquire as a result of their education and training).

35. LUBAN, LAWYERS AND JUSTICE, supra note 34, at 105-16.

36. Wasserstrom, Roles and Morality, supra note 34, at 25-29.

37. Different authors have called the principles by different names and defined the principles slightly differently. LUBAN, LAWYERS AND JUSTICE, supra note 34, at 7. For different formulations, see Postema, Moral Responsibility, supra note 24, at 73; Schwartz, Professionalism and Accountability, supra note 24, at 673; Simon, Ideology of Advocacy, supra note 24, at 36.

38. Postema, Moral Responsibility, supra note 24, at 73.

39. Id. at 73; Schwartz, Professionalism and Accountability, supra note 24, at 673; Simon, Ideology of Advocacy, supra note 24, at 36.

40. Postema, Moral Responsibility, supra note 24, at 74.

41. William H. Simon, The Practice of Justice: A Theory of Lawyers' Ethics 8 (1998).

42. Postema, Moral Responsibility, supra note 24, at 64 . 
problems of legal professionalism.

To create tension between role morality and ordinary morality, moral theorists gave the "limits of the law" and "client objective" parameters a particular and extreme interpretation. The "limits of the law" parameter was interpreted broadly to embrace any colorable interpretation that the law can arguably sustain - a style of interpretation David Luban called "zeal at the margin." ${ }^{43}$ Lawyers who advocate zealously at the margin of the law do not engage in good faith interpretation of the law, but treat legal limits instrumentally, looking for ways around or loopholes through them. ${ }^{44}$ Accordingly, they push the "limits of the law" that are meant to constrain the pursuit of their clients' interests "well past whatever moral and political insight constitutes the 'spirit' of the law in question." ${ }^{45}$ Defined in these terms, the "limits of the law" are not really limits at all; they are challenges to the cleverness and gamesmanship of lawyers. ${ }^{46}$ Because "zeal at the margin" was defined as pushing law beyond moral limits, the pursuit of "zeal at the margin" was virtually guaranteed to generate conflicts between role morality and ordinary morality.

Lawyers, however, cannot get out to the margin of the law and morality on their own. The standard conception defines a lawyer's partisan duties as the loyal pursuit of a client's objectives. ${ }^{47}$ A lawyer is unlikely to experience conflicts between ordinary and role morality when representing altruistic clients whose objectives include "doing the right thing" and treating others fairly. Even clients who are motivated primarily by self-interest but still care about containing litigation costs, preserving long-standing business relationships with present adversaries, or maintaining their reputations in the community will have an interest in avoiding the far reaches of "zeal at the margin." to the margin where the philosophically interesting conflicts arise, legal ethicists had to construct clients whose objectives were defined solely in terms of maximizing their legal interests-their wealth, freedom, or power over others-in disregard of the consequences to others and in disregard of their own long-term relationship and reputational interests.

Only by equating "zeal at the margin" with being a "good lawyer" can the critiques raised by early legal ethics scholars become critiques of legal professionalism, rather than critiques of bad lawyering. If a good person could be a good lawyer most of the time, the conflicts between role morality and ordinary morality would materialize in only exceptional cases. Furthermore, a critique of

43. David Luban, The Adversary System Excuse, in Legal Ethics and Human Dignity 19, 26 (2007) ("[Z]ealous advocacy always means zeal at the margin.").

44. Id. at 25-26; LUBAN, LAWYERS AND JUSTICE, supra note 34, at 16-17.

45. Luban, Adversary System Excuse, supra note 43, at 26.

46. LUBAN, LAWYERS AND JUSTICE, supra note 34, at 17.

47. Postema, Moral Responsibility, supra note 24, at 73; MODEL RuLES R. 1.2(a) (a lawyer is to abide by a client's decision regarding the objectives of representation).

48. See Ted Schneyer, Some Sympathy for the Hired Gun, 41 J. LEGAL EdUC. 11, 26-27 (1991). 
the exceptional case does not serve the theoretical purpose of demonstrating how the professional ideal itself, the "role morality" of lawyers, is morally corrupt.

\section{B. CRITIQUES OF THE STANDARD CONCEPTION}

Moral theorists mounted essentially two critiques of the standard conception, one of which focused on the viability of public policy justifications for lawyers' partisan dedication to their clients' interests and the other of which focused on whether lawyers who practiced according to the standard conception could themselves be good persons. These critiques, however, depended for their force and vitality on a vision of lawyers who push the law as far as it could go out of loyalty to cardboard clients bent on wrongdoing and unable to be persuaded off that course.

\section{The "Adversary System ExcuSE" Critique}

Early moral theoretical writings questioned the adequacy of traditional appeals to the adversary system to justify lawyers' representation of morally reprehensible clients or the use of morally questionable tactics. ${ }^{49}$ Adversarial partisan ethics are traditionally justified by arguing that the zealous pursuit of a client's interests ultimately serves public goals even if it produces what seems like injustice in the situation at hand. ${ }^{50}$ This traditional view of the adversary system, into which members of the legal profession are socialized, is defended by utilitarian arguments that adversarial testing leads to more accurate truth-finding, procedural justice arguments about the power of adversarial proceedings in effectuating the legitimacy of law, and the consonance of partisan representation with liberal democratic values of individual autonomy, dignity, and fairness. ${ }^{51}$

Moral theorists responded that the standard conception and its endorsement of instrumental manipulation of the law to maximize a client's legal interests may accurately capture a lawyer's moral duties in some kinds of legal practice, most notably criminal defense. ${ }^{52}$ The moral theorists contended, however, that lawyers wrongly invoke arguments based on the adversary system even outside the

49. Wasserstrom, Lawyers as Professionals, supra note 23, at 12.

50. The most prominent early example is FrEedMAN, LAWYERS' ETHICS, supra note 19.

51. See generally Monroe H. FreEdMan \& AbBe SMith, Understanding LaWyers' Ethics 13-43 (3d ed. 2004) (cataloguing systemic arguments in favor of adversarial ethics); Pepper, Ethical Role, supra note 24.

52. Moral theorists generally have excused criminal defense lawyers from ordinary moral obligations, noting the different public policies at stake in criminal defense. See, e.g., David Luban, Are Criminal Defenders Different?, 91 MiCh. L. REv. 1729 (1993); Murray L. Schwartz, On Making the True Look False and the False Look True, 41 Sw. L.J. 1135, 1141 (1988). But see William H. Simon, The Ethics of Criminal Defense, 91 MICH. L. REV. 1703 (1993). 
contexts in which partisan zeal is justified, such as non-litigation settings ${ }^{53}$ and civil litigation between private parties. ${ }^{54}$ In the best-known and most sustained theoretical critique of the lawyer's partisan role, David Luban systematically critiqued arguments that the adversary system was the best way to determine truth, the best way to protect legal rights, or the best way to reflect society's commitment to enhancing personal autonomy and protecting human dignity. ${ }^{55}$

Rather than relying on blanket appeals to the "adversary system excuse" to justify their behavior, Luban argued that lawyers should take into account the moral justifications for their adversarial role and weigh the strength of those justifications against the moral harm that adhering to the role would cause. ${ }^{56}$ Where a lawyer represents an individual squaring off against the state or a powerful institution, exemplified by the paradigm of criminal defense, Luban argued that the moral justifications for the adversary system are strong and typically require "the kind of partisan zeal characterized in the standard conception." Where clients possess power equal to or greater than their opponents, however, the adversary system is only weakly justified by the pragmatic argument that it "seems to do as good a job as any at finding truth and protecting legal rights," and because it is the system we already have ${ }^{58}$ Because the adversary system is so weakly justified in such cases, he concluded, it "doesn't excuse much more than the most minor deviations from common morality." 59

Though theoretically valid, Luban's critique of the "adversary system excuse" depended for its force on images of lawyers who manipulate the law, the facts, and the rules that govern their own behavior. For example, in critiquing the consequentialist argument that the adversary system is the best way to ascertain

53. Schwartz, Professionalism and Accountability, supra note 24, at 669 (arguing that justifications based on the adversary system do not hold in non-litigation contexts, such as negotiating and counseling, in which the corrective backstop of an impartial arbiter in missing).

54. Murray L. Schwartz, The Zeal of the Civil Advocate, in THE Good LAWYER, supra note 24, at 150 (lawyers in civil cases should be held morally accountable for the objectives of the clients they choose to represent and whether the tactics they employ assist or undermine the ascertainment of truth).

55. The critique was initially laid out in Luban's own contribution to THE GOOD LAWYER, entitled The Adversary System Excuse, which has been reprinted in a recent volume of essays, LEGAL ETHICS AND HUMAN DIGNITY, supra note 43. This essay was refined and expanded to cover five chapters of his book, LAWYERS AND JUSTICE. LUBAN, LAWYERS AND JUSTICE, supra note 34. William Simon has developed a similar critique of traditional justifications for adversary ethics. See SIMON, PRACTICE OF JUSTICE, supra note 41.

56. This weighing involves a four-step process, which is explained in detail in LUBAN, LAWYERS AND JUSTICE, supra note 34, at 128-47.

57. Id. at 148 .

58. Id. at 92. Luban suggests that lawyers in civil cases would be enjoined from deceitful practices and from inflicting "morally unjustifiable damage on other people." Id. at 157. They may not take exception from the general moral obligation of obedience to the law by manipulating the law "to achieve outcomes that negate its generality or violate its spirit." Id. Also, they may not pursue legally permissible but "substantively unjust results." Id.

59. Id. at 149. 
truth, he conjured the image of the zealous advocate who starts with the story that best serves the client's legal interests, and "reasons backwards to what the facts must be, dignifies this fantasy by labeling it her 'theory of the case,' and then cobbles together whatever evidence can be used to support this 'theory." ${ }^{\prime \prime 0}$ The problem with this kind of advocacy, he argued, is that it starts from the "standpoint of the client's interests" rather than from the client's actual perspective. ${ }^{61}$ Setting up one manipulative and misleading version of the facts against another equally manipulative and misleading version of the facts was more likely to result in obfuscation and confusion than the determination of truth. $^{62}$

Luban's argument against the claim that the adversary system is the best way to protect legal rights proceeded along a similar course. He conceded that individuals in society may need adversarial counsel to vindicate legitimate legal rights; however, he argued, invoking both "zeal at the margin" and cardboard clients, this need does not support "[t]he no-holds-barred zealous advocate [who] tries to get everything the law can give (if that is the client's wish)." ${ }^{63}$ When lawyers use "tricks of the trade" like delay tactics or driving up costs to gain a settlement, they are infringing their opponents' rights, not vindicating their clients' rights. $^{64}$

Luban's critiques of zealous partisanship also invoked the image of cardboard clients to discredit the notion that promoting individual autonomy and human dignity has intrinsic moral worth. The moral worth of pursuing autonomy or protecting dignity, he argued, derives from the goodness of the clients a lawyer represents. Appeals to autonomy cannot justify lawyers in helping individuals use their freedom under the law to cause unjustifiable harm and violate the autonomy of others. ${ }^{65}$ Likewise, honoring a client's human dignity by providing her with an advocate to tell her story is good only insofar as the lawyer tells the client's story in good faith. ${ }^{66}$ Lawyers who use the law to help clients bully others, manipulate legal processes, or deliberately distort the facts cannot rely on appeals to autonomy and dignity to justify the adversary system's "peculiar requirement of one-sided zeal at the margin of the legal and the moral."

\section{The Role Disposition CRITIQue}

Although the "adversary system excuse" critique focused on the adequacy of
60. Id. at 73 .
61. Id.
62. Id. at 68-74.
63. Id. at 75 .
64. Id.
65. See id. at 82-83; see also Luban, Lysistratian Prerogative, supra note 24
66. LUBAN, LAWYERS AND JUSTICE, supra note 34 , at 86-87.
67. Id. at 84 . 
public policy justifications for adversarial zeal, the second critique was concerned primarily with what Daniel Markovits has called "legal ethics from the lawyer's point of view." ${ }^{\text {"F8 }}$ From the lawyer's point of view, the issue is not how to justify role-differentiated behavior to the rest of society, but how lawyers personally cope with the moral wrongs that their profession requires them to commit. ${ }^{69}$ What is at stake is the lawyer's personal integrity or ability to live according to values that he has chosen and can endorse as part of a coherent life plan. $^{70}$

The role disposition theorists' critique draws on a tradition pioneered by philosopher Bernard Williams, which focuses on the way moral agents experience moral obligation. ${ }^{71}$ As a philosopher, Williams is known for his colorful examples illustrating the internal experience of morality: a lorry driver who accidentally runs over a young child ${ }^{72}$ and the plight of Jim, a man forced by a military dictator to personally execute an innocent villager to prevent the dictator from executing twenty innocents. ${ }^{73}$ Williams's philosophical work builds on the strongly intuitive notion that our moral concerns in these situations cannot be fully expiated by telling us that the moral harm we cause, injuring a child by accident or executing an innocent person under coercion, is not really our fault. ${ }^{74}$ A theory that delivers the answer that causing such harm "is not morally wrong" is incomplete because it fails to capture the moral experience of acting, or being forced to act, contrary to one's own values.

Legal ethics scholars have used Williams's examples of the lorry driver and Jim and the villagers as analogies for the situation of lawyers whose professional role obligations require them to act contrary to ordinary moral obligations. ${ }^{75}$ The problem with the standard conception, these scholars argued, is that it defines a

68. Daniel Markovits, Legal Ethics from the Lawyer's Point of View, 15 YALE J.L. \& HUMAN. 209 (2003).

69. See id. at 220.

70. Id. at 223 .

71. See B.A.O. Williams, Ethical Consistency, in PRACTICAL REASONING 91 (Joseph Raz ed., 1978) (discussing the nature of conflicts between one's own competing moral judgments); Bernard Williams, Moral Luck, in WILLIAMS, MORAL LUCK, supra note 27, at 27 (discussing the phenomenon of "agent-regret" we feel upon causing harm accidentally); Bernard Williams, A Critique of Utilitarianism, in J.J.C. SMART \& BERNARD WILLIAMS, UTILITARIANISM: FOR AND AGAINST (1973) (describing the failure of utilitarianism to capture the moral experience of being required to commit a moral wrong in order to optimize moral outcomes).

72. Williams, Moral Luck, in WILLIAMS, MORAL LUCK, supra note 27, at 28.

73. Williams, A Critique of Utilitarianism, supra note 71, at 98.

74. For example Williams argues that the lorry driver should feel a special kind of "agent-regret" that is different from the regret felt by a spectator who witnessed the accident. Williams, Moral Luck, in WILIAMS, MORAL LUCK, supra note 27, at 28. Likewise, although Jim would be morally justified in accepting the dictator's invitation-and Jim might even be morally self-indulgent if he refused it-killing an innocent villager by his own hand still alienates Jim from himself and from projects close to the center of his moral personality in a way that observing someone else commit the deed would not.

75. See, e.g., Postema, Moral Responsibility, supra note 24, at 68-69 (discussing the lorry driver example); Markovits, supra note 68, at 225-41 (extended analysis of Williams's example of Jim and the Villagers as applied to lawyers). Williams himself suggested that the creation of a professional class of amoral lawyers was perhaps a necessary evil that society tolerates because lawyers need to get their hands dirty if they are to get their 
"good lawyer" as a lawyer who can carry out partisan duties without experiencing personal moral qualms, and it thus encourages lawyers to embrace moral detachment in their professional work. ${ }^{76}$ Following in Williams's tradition, the legal ethics scholars argued that moral detachment is ultimately an ineffective strategy for coping with the deviations from ordinary morality that lawyers' professional role requires because it creates a disposition toward amorality that aggravates the level of harm that lawyers are willing to visit on others and is ultimately unsatisfying to lawyers themselves. ${ }^{77}$

Although Luban was clear in both defining "zeal at the margin" and directing his critique of adversary ethics against it, role disposition theorists did little to spell out the conditions that pose threats to lawyers' personal integrity. Role disposition theorists relied instead on vague assertions that legal representation requires lawyers to engage in unspecified "knavery,"78 or "require lawyers to lie, to cheat and to abuse." These theorists further claimed that a lawyer's personal integrity is put at issue by the very fact of legal representation because legal representation necessarily requires lawyers to disingenuously present legal and factual claims they do not personally believe. ${ }^{80}$

As critics have noted, however, the sweeping characterization of legal representation as "lying, cheating, and abusing" can be made only by stripping lawyers' acts from the contexts in which they are performed. ${ }^{81}$ Understood within the rules and expectations that govern the practice of law, many of the tactics that moral theorists target would not ordinarily be considered lying or cheating. ${ }^{82}$ In fact, some of the more abusive tactics cited by legal ethics scholars, such as asking invasive and embarrassing questions at a deposition, arguably cannot be understood outside the context of legal representation at all. ${ }^{83}$ Moreover, in

jobs done. See Bernard Williams, Politics and Moral Character, in WIlliams, Moral Luck, supra note 27, at 54, 63-66; Bemard Williams, Professional Morality, supra note 34, at 266.

76. Postema, Moral Responsibility, supra note 24, at 78.

77. Gerald J. Postema, Self-Image, in THE GOOD LAWYER, supra note 24, at 306 (arguing that professional detachment leads to a life characterized by "confusion, contradiction and self-deception"); $c f$. Postema, Moral Responsibility, supra note 24, at 68-69 (arguing that morally detached lawyers come to view the harm they cause as if they were spectators rather than participants).

78. See id. at 63; Postema, Self-Image, in THE GOOD LAWYER, supra note 24, at 288. Postema himself expressed doubt about the claim that "knavery" is a regular aspect of legal representation, adopting the characterization for purposes of argument, but noting his own view that the claim is "exaggerated and too often romanticized." Id. at 288.

79. Markovits, supra note 68 , at $217-19$.

80. Postema, Moral Responsibility, supra note 24, at 77; Markovits, supra note 68, at 218.

81. Ted Schneyer, The Promise and Problematics of Legal Ethics from the Lawyer's Point of View, 16 YALE J.L. \& Human. 45, 61-63 (2004).

82. Id. at $62-63$.

83. W. Bradley Wendel, Public Values and Professional Responsibility, 75 Notre Dame L. REv. 1, 29 (1999) ("[I]t is almost impossible to think of a relevantly similar case that would arise in everyday moral life, where an agent was duty-bound to ask embarrassing questions of complete strangers, while the strangers were absolutely required to answer them."). Williams's own view was that it was difficult to talk about divergences between 
Williams's examples, the extremity of the moral harm creates the threat to the agent's personal identity ${ }^{84} \mathrm{~A}$ lawyer who found her client's version of the facts plausible would be hard-pressed to claim that her personal integrity was placed in jeopardy by the fact of legal representation itself.

The role disposition theorists' claim that adherence to lawyers' professional role necessarily threatens lawyers' personal integrity begins to make sense only if we imagine that lawyers routinely represent clients with goals that transgress ordinary moral bounds. ${ }^{85}$ Like the critique of the "adversary system excuse," the role disposition theorists' critique is based on an implicit reliance on cardboard clients who push their lawyers up to and past the limits of the law.

\section{MORAL LAWYERS AS THE SOLUTION TO THE PROBLEMS OF LEGAL PROFESSIONALISM}

Although the critiques of traditional partisanship proceeded along two tracks, the "adversary system excuse" and the effect of legal representation on lawyers' moral characters, they converged on a common solution: lawyers should reject the moral neutrality inherent in the standard conception and draw on their independent moral judgment to reign in their partisan advocacy. The purpose of importing ordinary moral considerations into legal representation was to supplement the parameters defining professional behavior under the standard conception-client objectives and the limits of the law-with additional constraints based on the assessments of right and wrong that lawyers would make outside their professional roles.

Luban's alternative ideal of professionalism, which he called moral activism, imposed on lawyers the moral responsibility to "break role" in compelling moral circumstances to respond to the human pathos of those on whom harm would be visited as a result of adhering to professional role obligations. ${ }^{86}$ To address the deleterious effects of the standard conception on lawyers' moral characters, Gerald Postema made the similar suggestion that lawyers should replace the standard conception's strategies of moral detachment with the exercise of

ordinary morality and role morality by focusing on lawyers' actions because "the same act can be acceptable in some contexts and not in others." Williams, Professional Morality, supra note 34, at 260-61.

84. Postema, Moral Responsibility, supra note 24, at 75 (" [A]s the moral distance between private and professional moralities increases, the temptation to adopt one or the other extreme strategy of identification also increases: one either increasingly identifies with the role or seeks resolutely to detach oneself from it."); Williams, Professional Morality, supra note 34, at 263-64.

85. See Markovits, supra note 68, at 262-63 (arguing that it is the routine and habitual nature of lawyers' wrongdoing, rather than its severity, that erodes a lawyer's moral character).

86. Luban calls this the "morality of acknowledgment." LUBAN, LAWYERS AND JUSTICE, supra note 34, at 127; see also David Luban, Freedom and Constraint in Legal Ethics: Some Mid-Course Corrections to Lawyers and Justice, 49 MD. L. REv. 424, 451-52 (1990) (clarifying that the duty to "break role" in compelling moral circumstances captured the truest essence of his alternative ideal of moral activism). 
"engaged moral judgment." ${ }^{\text {" R7 }}$ Rather than viewing their role as fixed by the standard conception of neutral partisanship, he advocated that lawyers cultivate "mature, responsible moral judgment in the[ir] professional activities," ${ }^{88}$ drawing on a broad range of "ordinary moral beliefs, attitudes, feelings, and relationships." 89

Although the prospect of lawyers exercising responsible moral judgment sounds unobjectionable, even appealing, moral theorists imported it into their alternative ideals of professionalism along with problematic assumptions about lawyers and clients. As discussed above, to create the kind of dilemmas they wanted to discuss, moral theorists assumed that clients were basically selfinterested and uncaring toward others. In formulating their solution, the moral theorists made the opposite assumption about lawyers, whom they posited as primarily motivated to lead moral lives and pursue the public interest. The alternative ideal of professionalism that emerged from these assumptions of moral lawyers and cardboard clients positioned lawyers as the moral and social conscience of legal representation, providing a necessary check on the selfseeking behavior of their clients.

When he first introduced his solution to the critique of the "adversary system excuse," David Luban was skeptical that holding lawyers morally accountable would have much of an impact on the profession. "Lawyers get paid for their services, not for their consciences," he wrote, "and criticizing an ideology won't change the world." ${ }^{90}$ In later writings, he increasingly came to identify moral activism with an alternative ideal historically situated within legal professionalism. ${ }^{91} \mathrm{He}$ connected moral activism with a "noblesse oblige" tradition rooted in the functionalist sociology of Talcott Parsons and the progressive politics of Louis Brandeis, which viewed lawyers as public servants mediating between clients' self-interest and the public good. ${ }^{92}$

The vision of "gentleman lawyers" or "lawyer-statesmen" who act as buffers between self-interested clients and the public good gained currency in legal ethics in the decades following Luban's articulation of the moral activist ideal. ${ }^{93}$ Some legal ethics scholars trace the roots of this vision to a republican notion of lawyers as a "virtuous elite" whose professional autonomy and freedom from

87. Postema, Moral Responsibility, supra note 24, at 83 (emphasis in the original).

88. Id.; Postema, Self-Image, in THE GOOD LAWYER, supra note 24, at 289.

89. Postema, Moral Responsibility, supra note 24, at 78.

90. LUBAN, Adversary System Excuse, supra note 43, at 63-64.

91. LUBAN, LAWYERS AND JUSTICE, supra note 34, at 160.

92. David Luban, The Noblesse Oblige Tradition in the Practice of Law, 41 VAND. L. Rev. 717,739 (1988) (the lawyer is "a buffer who mediates between illegitimate client desires and the social interest"). For a similar view, see generally William H. Simon, Babbitt v. Brandeis: The Decline of the Professional Ideal, 37 STAN. L. REV. 565 (1985).

93. See, e.g., Anthony T. Kronman, The Lost Lawyer: Falling Ideals of the Legal Profession (1993); Robert W. Gordon, The Independence of Lawyers, 68 B.U. L. REv. 1, 11-19 (1988); Russell G. Pearce, Rediscovering the Republican Origins of the Legal Ethics Code, 6 GEO. J. LEGAL ETHICs 241, 250-56 (1992). 
market forces position them well to secure the goods that would allow society to flourish. ${ }^{94}$ Others posit that lawyers' professional training and experience endow them with superior capacities of deliberation and practical judgment that specially equip them for the role of wise counselors. ${ }^{95}$ The very notion of professionalism has been understood by some as an attempt to recapture in neutral and egalitarian terms a "gentleman's ethic" more characteristic of a bygone age in which lawyers were recognized as "America's aristocracy."

As critics are quick to point out, however, the image of the "gentleman lawyer" has profoundly inegalitarian roots in elitist practices that historically excluded women, blacks, Jews, and Eastern European immigrants from the profession of law. ${ }^{97}$ The biggest challenge for those who hearken back to the lawyer-statesman ideal is whether the vision of the lawyer-statesman in egalitarian terms can be recast, or whether elitism is an inherent part of the vision.

When you play out the picture of moral activist lawyers who "take it upon themselves to judge and shape client projects" to fit the common good, ${ }^{98}$ the problems begin to become apparent. For example, lawyers following Luban's "moral activist" model of client counseling will employ increasingly intrusive techniques that begin with appealing to clients' consciences and inventing alternative ways for clients to satisfy their interests. If those tactics do not dissuade the client, moral activist lawyers may go on to mislead clients by emphasizing or exaggerating the probability of negative consequences of an immoral course of action or threatening to withdraw, which would cost the client money and perhaps even legal representation. If all else fails, the lawyer will betray the client by acting in accordance with the lawyer's own values, even over the client's objection. ${ }^{99}$

In a particularly heavy-handed description of moral activist representation, Luban describes the "lawyer for the damned" who "takes on cases that no one else will come near, cases in which the client has for one reason or another rightly become odious or untouchable in the eyes of mankind." 100 In accepting representation of such odious clients, the lawyer "attempt[s] not merely to save the client from the consequences of her deeds but to transform and redeem her." 101 Luban followed his discussion of lawyers "transforming and redeeming" their clients by extolling a 1905 speech in which Louis Brandeis commended the

94. Pearce, supra note 93, at 250-56; Gordon, supra note 93, at 14-16.

95. KronMan, supra note 93, at 115-16.

96. Thomas L. Shaffer \& MARy M. ShafFer, American Lawyers and TheIr Communities: Ethics IN THE Legal Profession 48-49 (1991); see also Pearce, supra note 93, at 250-56; Gordon, supra note 93, at 16-19.

97. W. Bradley Wendel, Nonlegal Regulation of the Legal Profession: Social Norms in Professional Communities, 54 VAND. L. REv. 1955, 2025-28 (2001); SHAFFER \& SHAFFER, supra note 96, at 48-49.

98. Luban, Noblesse Oblige Tradition, supra note 92, at 737-38.

99. Id.; LUBAN, LAWYERS AND JUSTICE, supra note 34, at 173-74.

100. Id. at 162.

101. Id. (emphasis added). 
superior practical wisdom of lawyers, which Brandeis suggested endowed lawyers with "a position materially different from that of other men ... the position of the adviser of men."102

The combination of evangelism and elitism in these references paints a rather frightening picture of the lawyer-client relationship, and to his credit, Luban has explicitly disclaimed its most disturbing aspects. Lawyers, he has suggested, are not "more virtuous, decent courageous or compassionate than the rest of us" but have "the same moral insight as anyone else."103 Moreover, he has insisted, the heart of moral activist client counseling is best described as "discussing with the client the rightness and wrongness of her projects and the possible impact of those projects on 'the people' in the same matter-of-fact and (one hopes) unmoralistic manner that one discusses the financial aspects of a representation." 104 Other legal ethics scholarship has endorsed similarly less heavy-handed visions of moral counseling, in which lawyers discuss the moral implications of a client's options as a matter of course, raising questions as to whether the client's proposed courses of action would be "right" or "fair." ${ }^{105}$ To raise these questions, however, seems to beg them. It is not common to question the rightness or fairness of a course of action in ordinary conversation unless one is experiencing moral qualms about pursuing it.

Moreover, however benignly the goals of moral activist counseling are stated, the moral activist approach has an inherent tendency to veer in the direction of moral elitism. ${ }^{106}$ To defend moral activism as a method for correcting the course of an errant client, one has to explain why lawyers are better situated than their clients to exercise responsible moral judgment in legal representation. Moral theorists face a major obstacle in that regard. Ordinary morality applies to us because we are persons, and lawyers and clients are on an equal moral footing as

102. Id. at 170, quoting Louis D. Brandeis, Opportunity in the Law.

103. LUBAN, LAWYERS AND JUSTICE, supra note 34, at 171.

104. David Luban, Partisanship, Betrayal and Autonomy in the Lawyer-Client Relationship, 90 Colum. L. REV. 1004, 1026 (1990), quoting LUBAN, LAWYERS AND JUSTICE, supra note 34, at 173. He clarified that the references to lawyers "transforming and redeeming" their clients were meant for the special case of the "odious or untouchable" client and did not represent the heart of his view of client counseling. Luban, Partisanship, Betrayal and Autonomy, supra, at 1025. And, he cautioned that lawyers should remain open to the "possibility that it is the lawyer rather than the client who will eventually modify her moral stance." LUBAN, LAWYERS AND JUSTICE, supra note 34, at 174.

105. For examples, see Thomas L. Shaffer \& Robert F. Cochran, Jr., Lawyers, Clients and Moral ResponsibIlity (2d ed. 2009); Bruce A. Green \& Russell L. Pearce, "Public Service Must Begin at Home": The Lawyer as Civics Teacher in Everyday Practice, 50 WM. \& MARY L. Rev. 1207 (2009); Stephen L. Pepper, Lawyers' Ethics in the Gap Between Law and Justice, 40 S. TEx. L. Rev. 181 (1999); Deborah L. Rhode, Moral Counseling, 75 FORDHAM L. REV. 1317 (2006).

106. Luban has emphasized that the "element of truth" in Brandeis's speech was that lawyers are better situated than their clients to consider the common good. Luban, Noblesse Oblige Tradition, supra note 92, at 725. And, he has more than one time suggested that lawyers should see it as their responsibility to "make their clients better" and actively "steer their clients in the direction of the public good." Id. at 721; LUBAN, LAWYERS AND JUSTICE, supra note 34, at 171. 
persons. The demands of "ordinary morality" are therefore inherently egalitarian; they do not depend on social status, professional training, or expertise. Unless one can provide an explanation of why lawyers are better situated than clients to exercise responsible moral judgment, the chances of advancing the public good by pursuing the client's moral choices would seem to be just as great as the chances of advancing the public good by shaping client objectives according to the lawyer's moral choices. ${ }^{107}$

Finally, if one posits a morally pluralistic society in which different and divergent reasonable conceptions of the requirements of morality exist, the idea of lawyers policing the morality of their clients' objectives becomes especially problematic. ${ }^{108}$ The lawyer-statesman ideal requires lawyers to assess both the public good and their clients' deviance from the public good. Judgments about the public good, however, depend on the application of moral standards about which persons in a morally pluralistic society may reasonably disagree. ${ }^{109}$ If lawyers impose limits on the pursuit of their clients' legal interests that spring from their own understanding of morality, they abandon their public role as channels through which clients can access the law. ${ }^{110}$

The early moral theorists in legal ethics did not confront the challenges that moral pluralism presented to their ideal of the lawyer-statesman, nor did they endeavor to explain why lawyers are better situated than clients to take moral responsibility for the decisions made in legal representation. By staying within the assumptions of moral lawyers and cardboard clients, legal ethics scholars were able to posit clients as self-interested and morally suspect and lawyers as repositories of public values.

Because the early moral theorists critiqued an extreme and narrow vision of partisanship, they concluded that the parameters that define lawyers' professional duties under the standard conception-client objectives and the limits of the law-were too weak to constrain lawyers from harming third parties and eroding the public interest. Legal ethics scholars did not question whether legal practice according to the standard conception served clients well; they assumed that it

107. See infra Part III.E on whether lawyers are better situated to make moral decisions in legal representation.

108. The problems that moral pluralism pose for legal ethical theories are a subject of increasing attention within legal ethics. See generally Rob Atkinson, Beyond the New Role Morality for Lawyers, $51 \mathrm{MD}$. L. REv. 853 (1992); Katherine R. Kruse, Lawyers, Justice and the Challenge of Moral Pluralism, 90 MinN. L. Rev. 389 (2005); Thomas D. Morgan \& Robert W. Tuttle, Legal Representation in a Pluralist Society, 63 GEO. WASH. L. REv. 984 (1995); Norman W. Spaulding, Reinterpreting Professional Identity, 74 U. CoLo. L. Rev. 1, 76-90 (2003); W. Bradley Wendel, Public Values and Professional Responsibility, 75 Notre Dame L. Rev. 1 (1999).

109. For a more extended version of this argument, see Katherine R. Kruse, Lawyers, Clients and the Challenge of Moral Pluralism, 90 MiNN. L. REv. 389 (2005).

110. Stephen L. Pepper, A Rejoinder to Professors Kaufman and Luban, 1986 AM. B. FouND. REs. J. 657, 666; see also W. Bradley Wendel, Civil Obedience, 104 CoLuM. L. Rev. 363, 363 (2004). 
did. ${ }^{111}$ These scholars did not consider alternative ideals of partisanship that would encourage lawyers to be more sensitive to clients' concerns because in their view, lawyers were already overly solicitous of clients. The ethicists focused their attention on whether unmitigated partisanship served the public well and whether it allowed lawyers to lead morally defensible lives. Having concluded that it failed on both scores, the ethicists sought solutions that would bolster lawyers' duties to the public at the expense of their loyalty to their clients.

The focus on moral lawyers and cardboard clients prevented the early ethicists from exploring the possibility that the real problems of legal professionalism might originate not primarily from selfish clients who push their lawyers to the limits of the law, but primarily from lawyers who focus too narrowly on their clients' legal interests and fail to view their clients as whole persons with a myriad of non-legal concerns. The next Part explores how theoretical legal ethics might have developed if moral theorists pursued the problem of legal objectification as the central moral problem of legal professionalism.

\section{The Road Not Taken: Legal Objectification as the Central Problem of Legal Professionalism}

A serious analysis of the problem of legal objectification is a road not taken by legal ethics scholars. But it is a road that could have been taken. This Part traces the potential of legal objectification as a serious object of philosophical inquiry in legal ethics, noting that the earliest essay outlining the moral issues in legal professionalism identified the problem of legal objectification and called for a solution of limited deprofessionalization to decrease the professional distance between lawyers and clients. A concurrent movement in the legal interviewing and counseling literature advocated a client-centered approach to legal representation that reoriented the lawyer-client relationship in ways responsive to the problem of legal objectification. Had these two threads of study come together, they could have redefined the problems with legal professionalism and led to less problematic solutions than appeals to the lawyer-statesman model.

\section{A. WASSERSTROM'S LOST CONCERN FOR LEGAL OBJECTIFICATION}

In 1975, Richard Wasserstrom published a groundbreaking essay that raised "two moral criticisms of lawyers," each of which "concern[ed] the lawyer-client

111. Postema is an exception. In his early essay, he argued that moral detachment adversely affected the lawyer-client relationship by disengaging lawyers' abilities to relate to their clients as persons and to recognize the clients' own moral personalities. Postema, Moral Responsibility, supra note 24, at 80 . However, the solution he proposed left the moral direction of legal representation in the hands of lawyers with no guidance as to the meaning or goals of morally engaged partisanship. In a follow-up essay, the concern for clients was absent from discussion and Postema focused on the effects of amoral lawyering on the personal integrity of lawyers. Postema, Self-Image, in THE GOOD LAWYER, supra note 24. 
relationship." 112 The first criticism was the familiar concern that in carrying out their professional role obligations, lawyers were required to further the interests of morally unworthy clients and to disregard the moral harm that partisan advocacy visits on others. ${ }^{113}$ As discussed in Part $I$, this criticism of legal professionalism came to dominate the discourse as legal ethics scholars framed the moral issues in legal ethics as conflicts between role morality and ordinary morality.

Wasserstrom's second moral criticism is less familiar: the lawyer-client relationship is itself morally suspect because lawyers tend to objectify their clients in legal terms and to treat them paternalistically. ${ }^{114}$ "[F]rom the professional's point of view," he wrote, "the client is seen and responded to more like an object than a human being, and more like a child than an adult." ${ }^{115}$ Legal ethics scholars devoted limited attention to the problem of lawyer paternalism, treating a client "more like a child than an adult."116 Legal ethics scholars, however, have largely ignored the problem of lawyers' objectification of their clients, treating a client "more like an object than a human being," as a moral problem in its own right. ${ }^{117}$

What is hardly ever discussed or perhaps not even noticed is that Wasserstrom viewed his two moral criticisms as aspects of a single underlying pathology. ${ }^{118}$ Wasserstrom noted that, paradoxically, a lawyer could be both excessively preoccupied with a client's concerns and inattentive to the client. ${ }^{119} \mathrm{He}$ explained that the lawyer accomplishes both by being "overly concerned with the interest of the client and at the same time fail[ing] to view the client as a whole person."120 According to Wasserstrom, lawyers are not alone; all professionals tend to objectify their clients or patients by focusing attention on the subject matter of their expertise. Professionals in medicine, law, and psychology tend to view a client or patient "not as a whole person but a segment or aspect of a person-an interesting kidney problem, a routine marijuana possession case, or another adolescent with an identity crisis." ${ }^{21}$ For lawyers, the problem of legal objectification arises from viewing clients narrowly in terms of their legal

112. Wasserstrom, Lawyers as Professionals, supra note 23, at 1 .

113. Id. at 3-4.

114. Id. at 1 .

115. Id. at 19 (emphasis added).

116. See generally Luban, Paternalism, supra note 24; William H. Simon, Lawyer Advice and Client Autonomy: Mrs. Jones's Case, 50 MD. L. Rev. 213 (1991). But see David Luban, Introduction, in THE ETHICs of LAWYERS xi, xiv (1994) (noting that the issue of lawyers' paternalism toward clients has "attracted a much smaller philosophical literature" than the issue of harm caused by overzealous advocacy).

117. For limited exceptions in early legal ethical literature, see Warren Lehman, The Pursuit of a Client's Interests, 77 Mich. L. REv. 1078 (1979); Simon, Ideology of Advocacy, supra note 24.

118. Wasserstrom, Lawyers as Professionals, supra note 23, at 1, 15.

119. Id at 16 .

120. Id. (emphasis added).

121. Id. at 21 . 
interests alone.

The tendency of lawyers as professionals to objectify their clients reveals the two kinds of moral disregard for clients as whole persons and for anyone not a client as different aspects of the same problem. The root of the problem lies in the narrow definition lawyers give to their client's objectives. Clients arguably come to lawyers with the capacity and desire to be moral. Lawyers, with the analytical precision of their professional training, slough off clients' non-legal concerns and focus only on the legally relevant aspects of the case. Consonant with their professional training, lawyers "issue-spot" their clients as they would the facts in a law school exam, reducing client objectives to bundles of legal rights and interests. Lawyers then pursue those legal interests in disregard of both their clients' actual wishes and the harm caused to others. In the process, lawyers disregard their clients' inclinations to be cooperative, moral, and socially responsible and encourage the self-seeking behavior that accompanies legal interest maximization.

The solution Wasserstrom proposed to this underlying pathology of legal professionalism was a kind of limited "deprofessionalization" of the lawyerclient relationship. He did not go very far in elaborating what deprofessionalization might mean and he acknowledged that an adequate solution was difficult to envision because there were certain "important and distinctive competencies" that clients seek and lawyers possess. At the very end of his essay, Wasserstrom suggested that the key to solving the puzzle of limited deprofessionalization would have to "await an explicit effort to alter the ways in which lawyers are educated and acculturated to view themselves, their clients, and the relationships that ought to exist between them." 122

\section{B. REDEFINING THE PROBLEM: THE HIDDEN COMPLICITY OF LAWYERS IN SHAPING CLIENT OBJECTIVES}

In the view of early legal ethics scholars, lawyers' partisan loyalty and moral neutrality was the source of the moral and ethical problems that plagued legal professionalism. These ethicists defined the central problems of professionalism as stemming from lawyers' unquestioning deference to clients. Clients were the ones who pushed their lawyers to the limits of the law while the lawyers were required by professional duty to transgress the dictates of ordinary morality.

If, however, legal objectification is the central pathology of the legal profession, then pinning the problems on the standard conception's combination of partisan loyalty and moral neutrality is a misdiagnosis. If lawyers are responsible for transforming their clients from whole persons into bundles of legal interests, then lawyers are complicit in creating the conflicts between personal morality and professional role morality that the early ethicists observed.

122. Id. at 23 . 
Lawyers are complicit because they are responsible for defining the clients' objectives narrowly through legal interest maximization in the first place.

The idea that lawyers shape their clients' objectives based on a particular and professionalized perspective is supported by empirical research of the legal profession across a number of legal practice fields. ${ }^{123}$ In one recent study, for example, lawyers and clients in medical malpractice cases were surveyed to determine their view of plaintiffs' objectives in malpractice suits. When asked why plaintiffs sue, lawyers on all sides of litigation, representing doctors, hospitals and patients, "either immediately or ultimately described the issue as one of money-solely or primarily." 124 By contrast, the vast majority of medical malpractice plaintiffs did not cite money as their sole or even their primary motivation and sixty-five percent of plaintiffs did not even mention money until they were prompted. ${ }^{125}$ What plaintiffs said they wanted to gain by suing were admissions of responsibility, the prevention of harm to others, answers to their questions, retribution for misconduct, and apologies for the suffering caused by medical error. ${ }^{126}$ The study concluded that the discontinuity between lawyer and client understandings of clients' objectives was due in part to the fact that "lawyers are trained to operate according to rights and rules, applying law to facts and placing people and occurrences into legal categories." 127 As a consequence, lawyers endeavored to fit their clients' more emotional goals "into legally cognizable categories-ultimately relating to monetary compensation alone."128

The problem of legal objectification was discussed in a pair of other early legal ethics articles. In 1978, as one part of a sweeping critique of professional ideology, William Simon argued that lawyers who adhere to the dominant ideology of professionalism "impute certain basic aims to the client and ... work to advance these imputed ends." ${ }^{129}$ As Simon noted, the ends are defined on the basis of egoistic assumptions that "emphasize extreme selfishness." 130 Simon suggested that lawyers end up representing a "hypothetical person with only a few crude discrete ends" who bears little resemblance to the real client whose satisfaction relies on a complex balance of interrelated goals within the context of cooperative social relationships. ${ }^{131}$ In an essay published a year later, Warren

123. See generally Austin Sarat \& William L. F. Felstiner, Divorce Lawyers and Their Clients: Power and MEANING IN THE Legal Process (1995) (divorce); Tamara Relis, "It's Not About the Money!": A Theory on Misconceptions of Plaintiffs' Litigation Aims, 68 U. PTT. L. REV. 701 (2007) (medical malpractice); Marvin W. Mindes \& Alan C. Adcock, Trickster, Hero, Helper: A Report on the Lawyer Image, 1982 AM. B. FouND. REs. J. 177 (survey of lawyers and public on the image of lawyers).

124. Relis, supra note 123 , at 713 .

125. Id. at 721 .

126. Id. at 723 .

127. Id. at 740 .

128. Id. at 741 .

129. Simon, Ideology of Advocacy, supra note 24 , at 53.

130. Id. at 54 .

131. Id. at 55 . 
Lehman further developed Simon's point by analyzing how the lawyer's instrumentalist approach to legal advice based on the interests of a "standardized" client can distort the decision-making of clients, whose deference to their lawyers' expertise may cause them to overvalue factors like the tax consequences of important life decisions. ${ }^{132}$

Lawyers' complicity in shaping their clients' objectives was also revealed, though not explicitly discussed, in Luban's discussion of custody blackmail in divorce cases. Luban offered custody blackmail as an example of "precisely the sort of hardball tactic that would be virtually impossible to justify without the standard conception." 133 He described it as a practice in which "the divorcing father (at the behest of his attorney) threatens to demand joint custody unless the mother reduces her financial demands." ${ }^{134}$ It is beyond the bounds of morality, he argued, for "the zealous divorce lawyer [to] suggest[] custody blackmail to a father who has no desire for custody." 135 Such a lawyer "has wronged the wife and children, contributed to the social problem of emiserated divorced mothers, added to the general sexism of American society and abused the legal system."136

For Luban, custody blackmail exemplified the need for lawyers to break role and take moral charge of the legal representation by refusing to pursue a financial benefit for their clients at the cost of moral harm to others; however, custody blackmail is also precisely the sort of hardball tactic that it is difficult to imagine a divorcing father coming up with on his own. Luban's own description of the practice reveals the active participation of the divorce lawyer. The divorcing father makes the custody demand "at the behest of his attorney" who "suggests" it to him. The very definition of the tactic implies that the lawyer advances a claim for custody that the client doesn't really want to win. Lawyers are the ones who begin legal representation by constructing their clients narrowly in the image of the clients' legal interests; thus, lawyers are the ones likely to come up with the tactic of custody blackmail in the first place. ${ }^{137}$

132. Lehman, supra note 24 , at $1088-89$. Lehman relates two personal anecdotes in support of his point about tax consequences. In one, a client defers an intended gift until a more tax advantageous time and ends up dying in a car crash without ever bestowing the gift. Id. at 1088 . In the other, a widow recovering from alcoholism avoids going to a lawyer for advice on selling a house that has become an emotional and psychological burden to live in, fearful that she will be talked into delaying the sale to gain a tax advantage. Id. at 1089.

133. Luban, Partisanship, Betrayal and Autonomy, supra note 104, at 1016.

134. Id. at 1015 .

135. Id. at 1018 .

136. Id.

137. Because the practice of custody blackmail is an ethically marginal tactic, a lawyer who was morally disinclined to employ it could easily find support in professional standards of conduct. See MODEL RULES R. 4.4(a) ("In representing a client, a lawyer shall not use means that have no substantial purpose other than to embarrass, delay, or burden a third person."). 


\section{RE-DEFINING THE SOLUTION: THE CLIENT-CENTERED APPROACH TO LEGAL REPRESENTATION}

At about the same time Wasserstrom called for "an explicit effort to alter the ways in which lawyers are educated and acculturated to view themselves, their clients, and the relationships that ought to exist between them," ${ }^{138}$ legal education was in the nascent stages of a movement with just those goals. Also undergoing fluorescence in the mid-1970s, the clinical legal education movement was in the midst of developing a curriculum for teaching the skills and values of lawyering in the context of live client representation. ${ }^{139}$ However well cardboard clients worked to discuss dilemmas in the legal ethics classroom, they were ill-fitted to the clinical teaching context, in which law students developed relationships with actual clients and confronted the complexities of their clients' life situations in their fullest dimensions.

Scholars writing the client interviewing and counseling literature designed for clinical teaching developed a solution to the problem of legal objectification. The most prominent model of lawyering to emerge from the clinical legal education movement was the development of client-centered representation, an approach that encouraged lawyers to conceptualize legal representation as problemsolving, to attend to clients' non-legal needs, and to include them in participatory decision-making on matters of legal strategy. ${ }^{140}$ Client-centered representation is taught pervasively in law school clinical and lawyering skills courses and has since generated a rich body of practice and pedagogy-based scholarship about lawyering, much of which explores the internal dynamics of the lawyer-client relationship. ${ }^{141}$

The client-centered approach is directly responsive to the problem of legal objectification. It urges lawyers to unlearn the professional habit of "issuespotting" their clients and to approach their clients as whole persons who are more than the sum of their legal interests. The hallmarks of the client-centered approach include understanding the client's problem from the client's point of

138. Wasserstrom, Roles and Morality, in THE GOOD LAWYER, supra note 24, at 23.

139. The earliest clinical teaching materials focused on the acquisition of professional role by breaking down and analyzing the various aspects of legal representation that made up what Gary Bellow and Bea Moulton famously called "the lawyering process." GaRY Bellow \& BEA Moulton, The LaWyering Process: MATERIALS FOR CLINICAL INSTRUCTION IN ADVOCACY (1978). For a history of this pedagogical movement, see Symposium: Celebrating The Lawyering Process, 10 Clinical L. Rev. 1 (2003).

140. David A. Binder, et al., Lawyers as Counselors: A Client-Centered Approach 2-15 (1991). For a comprehensive examination of the history and theoretical basis for this approach, see Robert D. Dinerstein, Client-Centered Counseling: Reappraisal and Refinement, 32 ARIZ. L. REv. 501 (1990). For a survey of the growth and development of the client-centered approach into a multiplicity of closely-related lawyering theories, see Katherine R. Kruse, Fortress in the Sand: The Plural Values of Client-Centered Representation, 12 Clunical L. Rev. 369 (2006).

141. For a fuller description of the theories that have grown up in the critique, expansion and modification of the client-centered approach, see Kruse, Fortress in the Sand, supra note 140, at 375-99. 
view and shaping legal advice around the client's values. ${ }^{142}$ Under the client-centered approach, hearing clients' stories and understanding their values, cares, and commitments is the first step and a continuing duty of legal representation. ${ }^{143}$

The client-centered approach also reorients the lawyer-client relationship along the lines of limited de-professionalization foreshadowed by Wasserstrom's essay. In a highly professionalized conception of role, lawyers exercise maximum professional control over strategic decisions with minimal consultation from clients. ${ }^{144}$ In client-centered representation, the focus on understanding clients' objectives more broadly and holistically tends to break down the boundaries between legal and non-legal strategies for addressing clients' problems. ${ }^{145}$ By contrast, the lawyer-statesman ideal proposed by legal ethics scholars reinforces a highly professionalized view of the lawyer-client relationship. In addition to using professional expertise to shape tactical and strategic decisions, lawyers are encouraged to make professional judgments about morality and the public good. Some versions of the lawyer-statesman model view client influence and participation in representation decisions as a threat to the independence that lawyers need to establish and maintain to play an effective role as mediator between clients' self-interested objectives and the public interest. ${ }^{146}$

Yet, the conceptualization of client-centered representation developed in clinical legal education has been slow to catch on in legal ethics. As some have noted, although the client-centered approach is appropriate in the context of representing the poor and otherwise marginalized clients typically served in law school clinics, it may have limited application in the circles of highly-paid lawyers for high-powered clients. ${ }^{147}$ Moreover, as legal ethics has matured as an

142. BINDER ET AL., supra note 140, at 19-22. The client-centered approach is contrasted with more traditional approaches to lawyering, which "view client problems primarily in terms of existing doctrinal categories" and "seek the best 'legal' solutions to problems without fully exploring how those solutions meet clients' nonlegal as well as legal concerns." Id. at 17.

143. For discussion of techniques for helping lawyers hear and understand their clients' stories and perspectives, see Jane Harris Aiken, Striving to Teach "Justice, Fairness and Morality," 4 CLINICAL L. REv. 1 (1997); Jane H. Aiken, Provocateurs for Justice, 7 CLINICAL L. Rev. 287 (2001); Susan Bryant, The Five Habits: Building Cross-Cultural Competence in Lawyers, 8 CLINICAL L. REv. 65 (2001); Kimberly O'Leary, Using "Difference Analysis" to Teach Problem-Solving, 4 CLINICAL L. REV. 65 (1997).

144. Douglas E. Rosenthal, LaWyer and Client: Who's IN Charge? 7-28 (1974) (contrasting traditional and client-participatory professional relationships).

145. Kruse, Fortress in the Sand, supra note 140, at 392-94.

146. Gordon, supra note 93 , at 18.

147. See Stephen Ellmann, Lawyers and Clients, 34 UCLA L. Rev. 717, 718-19 (1987) (distinguishing contexts in which clients "enjoy economic leverage over their lawyers" from those in which lawyers' social status and expertise gives them power over clients); see also Dinerstein, supra note 140, at 521-23 (discussing whether "the historical relationship to poverty law means[s] that client-centered counseling should be restricted to representation of poor people"); Kimberly E. O'Leary, When Context Matters: How to Choose an Appropriate Client Counseling Model, 4 T.M. COOLEY J. PRAC. \& ClINICAL L. 103 (2001) (distinguishing practice settings in which client-centered practice is more or less appropriate). 
academic discipline, legal ethics scholars have increasingly gravitated toward analyzing the scandals and pressures of practice in the big law firm, where the vision of "zeal at the margin" is "alive and well" and the conflicts between role morality and ordinary morality can most clearly be found. ${ }^{148}$ Unfortunately, as the paths of clinical scholarship and legal ethics have diverged, Wasserstrom's early insight that connected lawyers' amoral attitude toward third parties outside the lawyer-client relationship to lawyers' amoral disregard for their clients as persons has been lost.

\section{Legal Ethics for Three-Dimensional Clients}

This Part weaves the insights of client-centered representation into legal ethics by proposing and defending a theoretical model of client value-based representation that redefines the standard conception's principles of partisanship and neutrality in the context of three-dimensional clients who come to legal representation with a mixture of values, commitments, relationships, hopes, dreams, and fears. This new conception starts from the premise that client objectives are complex and multidimensional and places client values, as the client defines them, at the center of a lawyer's partisan duties. When the pursuit of a client's objectives is redefined in the context of three-dimensional clients, the standard conception's principles of partisan loyalty and moral neutrality look different. This Part argues that the redefined versions of partisan loyalty and moral neutrality survive the critiques that legal ethics scholars leveled at the extreme version of partisanship captured by "zeal at the margin" without succumbing to the dangers of moral elitism and moral overreaching that the lawyer-statesman model presents.

\section{A. PUTTING CLIENT VALUES AT THE CENTER OF LEGAL REPRESENTATION}

In an early article on lawyer paternalism, ${ }^{149}$ David Luban provided a theoretical vocabulary of wants, values, and interests with untapped potential for addressing Wasserstrom's puzzle of limited deprofessionalization. Wasserstrom noted that the idea of limited deprofessionalization is difficult to implement because clients come to lawyers for help with problems that really do require legal expertise. Although reducing a client to nothing more than a bundle of legal interests is problematic, legal issue-spotting is a core competency of lawyering

148. Douglas N. Frenkel, et al., Introduction: Bringing Legal Realism to the Study of Ethics and Professionalism, 67 FORDHAM L. REv. 697, 703 (1998) (summarizing the conclusion of an empirical study of large-firm litigators' ethical attitudes that the standard conception was "alive and well"); see also Luban, Partisanship, Betrayal and Autonomy, supra note 104, at 1016 ("The true haven of the standard conception, however, is large-firm practice.").

149. Luban, Paternalism, supra note 24. 
and a necessary component of virtually all legal representation. ${ }^{150}$ The puzzle is in figuring out how to "weaken the bad consequences" of lawyers' tendency to professionalize the lawyer-client relationship "without destroying the good that lawyers do."151

Luban's theoretical vocabulary redefines client objectives in three dimensions, suggesting that client objectives are complex, ambiguous, and potentially conflicting. Luban theoretically distinguished three different aspects of a client's objectives, as follows:

- Wants are those things a client subjectively desires in the moment; they are like facts that exist but cannot be disputed. ${ }^{152}$

- Values are the desires with which a client most closely identifies, playing an important role in defining a client's larger life-plans and self-conceptions. ${ }^{153}$

- Interests are "generalizable means to any ultimate end"; ${ }^{154}$ they include freedom, wealth, health, power, and control over other people's actions. ${ }^{155}$ Interests are not valuable in themselves, but as means by which we can satisfy our wants and actualize our values. ${ }^{156}$

According to Luban's analysis, the touchstone for a lawyer's appropriate intervention into client decision-making is whether the intervention supports or undermines the client in actualizing her values. ${ }^{157}$ The primacy of client values emerges from the way Luban analyzes what a lawyer should do when clients' wants, interests, and values conflict. Luban argued that lawyers are justified in paternalistically manipulating clients to promote the clients' interests in favor of the clients' wants. ${ }^{158}$ If a client expresses the desire to deviate from the maximization of legal interests, Luban saw it as "the lawyer's job to voice the conservative and restrained point of view" from the standpoint of the client's interests. ${ }^{159}$ Because wants come and go, a lawyer who protects a client's interests can serve as a sort of "ego" to the client's "id," getting clients past the fleeting wants that dominate their desires in the moment and keeping their future

150. MODEl Rules R. 1.1, cmt. 2.

151. Wasserstrom, Roles and Morality, in THE GoOD LAWYER, supra note 24, at 23.

152. Luban, Paternalism, supra note 24 , at 468.

153. Id. at 470 .

154. Id. at 471 .

155. Id. at 466,471 .

156. Id. at 474 .

157. I have previously discussed respect for client values in terms of enhancing a client's autonomy. Kruse, Fortress in the Sand, supra note 140, at 399-414. When a lawyer overrides a client's wants in favor the client's interests, Luban calls it "justifiable paternalism." Luban, Paternalism, supra note 24, at 473. But see Simon, Mrs. Jones' Case, supra note 116, at 224 (arguing that refined versions of autonomy and paternalism converge in a view that would support a client in actualizing her own values).

158. Luban, Patemalism, supra note 24, at 472-74.

159. Id. at 493. 
options open. ${ }^{160}$ Lawyers are not justified, however, in paternalistically manipulating clients to further the clients' interests in ways that override the clients' values. ${ }^{161}$ Because values form the core of a client's personality, manipulating a client to act against the client's values is a violation of the client's personal integrity. ${ }^{162}$ Such paternalistic intervention cannot be justified because interests are not valuable in themselves; they derive their value from their utility as means toward other ends. ${ }^{163}$

When lawyers place the actualization of client values at the center of legal representation, lawyers see their job as assisting their clients in making decisions that are consistent with clients' most important goals and life plans. As Luban and other philosophers have discussed, values are the beliefs closest to the centers of our personalities, and which invest our lives with meaning. ${ }^{164}$ Values play a dual role in our lives, both motivating our actions and shaping the way we define ourselves. Our values are in one sense normative, providing reasons for our actions; ${ }^{165}$ but values also are expressions of our identity, defining who we are. Furthermore, values connect our motivation to act with how we define ourselves; by acting in accordance with our values, we become the persons we want to be. ${ }^{166}$

The process of assessing and clarifying our values in situations of value conflict may be difficult. Our deepest values are often opaque; we may be motivated by underlying values that we do not explicitly recognize, but that viewed over time tie our choices together in recognizable patterns. ${ }^{167}$ Moreover, our process of value clarification may be distorted by short-term and reactionary emotions like anger, fear, and insecurity. ${ }^{168}$ Alternately, we may succumb to rationalizations that sound like the articulation of our values, but which really are excuses for doing what we want to do in the moment. Value clarification is a process of self-reflection often triggered by experiences of confrontation and choice that helps penetrate the fog of confusion that may attend practical choices in the face of uncertainty. Value clarification serves to help us discover and order

160. Id. at 493; see also id. at 486 (arguing that the superiority of what he calls the Ideal of Prudence "lies in the flexibility of the goods $I$ have termed 'interests' in realizing our ambitions, not in the intrinsic merits of money or power ... in other words, in its breadth and not in its depth").

161. Luban, Paternalism, supra note 24 , at $472-74$.

162. Id. at 473 .

163. Id. at 474 ("[I]t is absurd . . to assume that interests constitute the dominant values in a human life.").

164. Id. at 470; Bernard Williams, Persons, Character and Morality, in MoRAL LuCK, supra note 27, at 1, 12-13 (describing "ground projects" through which we define our lives' success).

165. Christine KorsgaARD, The SourCes OF NoRMATIVITY 8 (1996) (normative statements "make claims on us; they command, oblige, recommend or guide").

166. For a discussion of this idea in the context of autonomy theory, see Kruse, Fortress in the Sand, supra note 140 , at $404-05$.

167. Luban, Paternalism, supra note 24 , at 470 . In later work, Luban has suggested that many times we do not experience the things we care the most about as being chosen by us, but rather we feel as if our values have chosen us. DAVId LUBAN, Lawyers As Upholders of Human Dignity (When They Aren't Busy Assaulting It), in LEGAL ETHICS AND HuMAN DignTT, supra note 43, at 65, 76.

168. Luban, Paternalism, supra note 24 , at 473. 
our values so that our lives reflect our values, and we can become the kind of persons we want to be. ${ }^{169}$

When clients come to lawyers for legal advice and representation, their legal issues are often entangled with values, projects, commitments, and relationships with others. Sometimes legal tasks may touch on a client's deeply held personal values, such as getting legal help to start up a business a client has always dreamed of having or helping a couple adopt a child. Sometimes legal action arises because a client was harmed by the actions of others: the client was fired from a job, hit by a car, or beaten by a spouse. Sometimes the client is accused of treating others unjustly: the client sexually harassed an employee, reneged on a deal, negligently allowed harm to others, or committed a crime. Other times clients come to lawyers to overcome barriers to doing day-to-day business: the client needs to negotiate a deal, to lease property, or to obtain a permit.

In discussions with clients, lawyers inevitably emphasize and order information in ways that influence clients' choices. ${ }^{170}$ Whether or not a lawyer discusses a client's other commitments, projects, relationships, or values, the client still experiences the legal interests within the context of these other considerations. The counseling approach the lawyer employs will alter the client's perspective in favor of particular considerations. If the lawyer believes that her role is to maximize the client's legal interests, the lawyer will take an approach that emphasizes legal interests over other considerations. In contrast, lawyers who believe that their role is to shape the representation around a client's values will give their clients space to clarify those values and make representation decisions that are consistent with those values.

As Luban pointed out, lawyers' tendency to focus on their clients' legal interests may be justified to the extent that it diverts clients from making impulsive decisions. If a client is experiencing loss, transition, or uncertainty about the future, such as in a divorce or in the aftermath of a serious life-changing injury, the protection of legal interests may be the most effective way to keep the client's future options open until she is able to adjust to dramatic changes in her life and prioritize her values. Where the threatened loss will severely impair the client's ability to pursue options in the future-as in criminal cases where defendants face substantial loss of liberty or even death-particularly strong imperatives exist to protect the client's legal interests in order to maintain avenues for the client's future ability to actualize her values.

Legal interest-based counseling, however, serves the actualization of the client's life goals only indirectly. Legal interests are not good in themselves; they

169. Christina Korsgaard sees the process of "reflective endorsement" as central to our ability to act autonomously - to give authoritative law to ourselves. See KORSGAARD, supra note 165, at 129.

170. See Simon, Mrs. Jones's Case, supra note 116, at 217-18 (describing how lawyers influence their clients' decision-making even when they are ostensibly providing clients with information about legal interests). 
are merely the channels by which clients can use the law to pursue and protect what they value in life. Protecting a client's legal interests helps the client only because interests are generalized means toward anyone's ends. The temporary restraint on impulsive decision-making that legal interests provide is valuable precisely because pursuing the wants of the moment may foreclose the client from actualizing more deeply-held values, goals, or life plans.

Counseling that proceeds on the assumption that clients merely want to maximize their legal interests is far from neutral. In the context of legal representation, where the client may be confronting new opportunities or battling fear, uncertainty, anger, or pain, counseling clients that they "should" do what is in their legal interests to do may distort the client's process of value clarification and encourage self-seeking choices. ${ }^{171}$ Lawyers who say "this is what you should do" when what they really mean is "this is what it is in your legal interests to do," may encourage clients to press their legal interests further than the clients might otherwise be inclined. Clients who might otherwise be motivated to act in the public interest may be dissuaded by their deference to a lawyer's professional expertise. Furthermore, if a client is experiencing hurt or anger, knowing how the law can be used to defeat the interests of others may provide the client with a way to rationalize selfish choices at the expense of the client's better moral judgment. Just as lawyers may seek refuge in the excuse, "that is not my job," clients may seek refuge in the excuse, "I am just following legal advice."172

When a lawyer approaches legal representation as a problem-solving endeavor shaped around the client's values, the client's own values provide a natural check on legal interest maximization. Like legal interests, appeals to client values help curb impulsive, fearful, or vengeful decisions. Rather than achieving this goal by appealing to a hypothetical client's standardized interests, however, client value clarification appeals directly to the individual client's own values. The purpose of value clarification in legal counseling is not to change the weight or priority of the client's values, though that might be a byproduct of the process. Rather, the purpose is to ensure that the client's representation decisions are consistent with and further the client's values.

The methods of client value clarification involve both actively listening to what the client wants and probing beneath the client's expressed desires. Client-centered interviewing literature, for example, suggests that the lawyer dedicate time early in a client's initial interview for open-ended questions and other active listening techniques that help the lawyer hear the client's problem in the client's own terms. ${ }^{173}$ Hearing the client's story as the client chooses to tell it is a key component of understanding what the client values and what it is about the legal representation that will threaten or further those values.

171. Lehman, supra note 24 , at 1088-89.

172. See Pepper, Lawyers' Ethics, supra note 105, at 189-90.

173. BINDER ET AL., supra note 140, at 88-93. 
Client value clarification also may require probing beneath the surface of a client's stated desires. As Warren Lehman suggested, when clients seek legal representation, their judgment and articulation of what they really want may be skewed. "We say we want justice when we want love. We say we were treated illegally when we were hurt. We insist upon our rights when we have been snubbed or cut. We want money when we feel impotent." ${ }^{174}$ Lehman noted that instead of inquiring about clients' deeper goals, most lawyers give instrumentalist advice on how to maximize outcomes based on the desires of a hypothetical "'standard client' for whom lawyers are wont to model their services." ${ }^{175}$ In contrast, lawyers interested in helping a client center decisions on the client's own values will help their clients contemplate how the decisions of the moment will affect the clients' development in the direction of becoming the kind of person each of them uniquely wants to be.

\section{B. PARTISAN LOYALTY FOR THREE-DIMENSIONAL CLIENTS}

The centering of legal representation on client values suggests a more defensible ideal of partisanship than the "zeal at the margin" for cardboard clients that has occupied legal ethical critique. As discussed above, the moral theorists' critiques of the standard conception drew their force from their extreme interpretation of partisan loyalty as "zeal at the margin" for clients who want nothing other than to maximize their legal interests up to and beyond the moral limits in the law. When this conception of partisanship is replaced with an ideal based on helping clients actualize their own values, the critiques lose much of their force.

Hidden within the adversary system critique is a defense of partisanship conceived more broadly as shaping legal representation around a client's actual values and fashioning advocacy around the stories that clients would tell about themselves. For example, Luban's argument against the truth-finding efficacy of adversarial proceedings was based on the observation that lawyers use a client's legal interests as a starting point from which to develop facts and present evidence to a decision-maker. The "theories of the case" that arise from this method are misleading because they are based, not on the client's actual perspective of what occurred, but on what it would be best to prove from the standpoint of the client's legal interests. ${ }^{176}$ Under client-value centered partisanship, advocacy would be focused on finding ways to connect clients' own stories

174. Lehman, supra note 24 , at 1081.

175. Id. at 1089 .

176. For a criticism of advocacy that proceeds from this perspective in disregard of a client's actual story, see Binny Miller, Give Them Back Their Lives: Recognizing Client Narrative in Case Theory, 93 MicH. L. Rev. 485 (1994). 
to themes and values reflected in the law. ${ }^{177}$ Luban conceded that developing facts from the actual perspectives of disputing clients, rather than from the standpoint of their competing interests, would support, not hinder, accurate truth-finding. ${ }^{178}$ Luban makes the same concession in his arguments that the adversary system cannot be defended on the grounds that it is the best way to protect legal rights or honor human dignity. He argued that appeals to legal rights and human dignity were insufficient to justify the "no-holds-barred" tactics that lawyers use to gain whatever advantage a lawyer can for a client. ${ }^{179} \mathrm{He}$ conceded that the adversary system could be defended quite strongly, however, ${ }^{180}$ when it gives a client the opportunity to tell her own story, precisely because the opportunity to be heard is an important way of honoring a client's dignity.

In his later work, Luban described in more detail an ideal of partisan advocacy based on upholding a client's dignity, in which lawyers strive to match the case theory the lawyer presents-the legal story the lawyer tells about a client in negotiation or litigation-with the cares, commitments, and concerns that are most central to the client. ${ }^{181}$ According to Luban, human dignity means "having a story of one's own," having a subjective view of the world in which one is at the center. ${ }^{182}$ Lawyers dignify their clients by giving voice to their clients, by "telling the client's story and interpreting the law from the client's viewpoint,"183 and "by giving the client voice and sparing the client the humiliation of being silenced and ignored."184 A lawyer calibrating legal representation to a client's values would be much less likely to cynically manipulate the facts or stretch the law to extract anything it could be made to give, and much more likely to look for ways to legitimate the client's values by connecting them to values reflected in the law.

Client value-centered partisanship also would survive the role disposition theorists' critique. This critique, as discussed above, is that the standard conception encourages lawyers to develop a professional disposition toward amorality, which dulls them to the harm they cause others and is ultimately unsatisfying to lawyers themselves. Client value-centered partisanship would

177. See, e.g., id; Robert D. Dinerstein, A Meditation on the Theoretics of Practice, 43 HASTINGS L.J. 971 (1992); Lucie E. White, Subordination, Rhetorical Survival Skills, and Sunday Shoes: Notes on the Hearing of Mrs. G., 38 BUFF. L. Rev. 1 (1990).

178. See LUBAN, LAWYERS AND JUSTICE, supra note 34, at 73 ("The more perspectives we have, the better informed our judgment will be.").

179. Id. at 75 .

180. Id. at 85-87.

181. LuBAN, Human Dignity, supra note 43, at 68-73 (endorsing an even stronger argument in favor of partisan advocacy based on the honoring the story that the client has to tell). Luban finds particularly persuasive the account of adversary ethics offered by philosopher Alan Donagan as part of the Working Group on Legal Ethics. Id. at 819. See Alan Donagan, Justifying Legal Practice in the Adversary System, in THE GOOD LAWYER, supra note 24, at 123.

182. LUBAN, Human Dignity, supra note 43 , at $70-71$.

183. Id. at 70 .

184. Id. at 72 . 
encourage the development of a very different disposition: a disposition based in the capacities for empathy and self-reflection. ${ }^{185}$ To seriously undertake the task of centering representation on client values, lawyers would endeavor to see the world as their clients see it. Unlike the disposition of amoral detachment, which is argued to be at the root of lawyer alienation and discontent, ${ }^{186}$ empathy with clients is noted as a source of internal motivation that can help sustain lawyers in their professional roles. ${ }^{187}$

In short, in the very places where "zeal at the margin" fails to stand up to the deeper scrutiny of the early legal ethics scholars' critiques, client value-centered partisanship survives. The critiques of the moral theorists are quite forceful when leveled against the extreme vision of partisanship captured by "zeal at the margin." Yet, if ideal partisanship is conceived as being centered on client value actualization, a more defensible, even honorable, version of partisan loyalty emerges.

\section{MORAL NEUTRALITY FOR THREE-DIMENSIONAL CLIENTS}

In addition to critiquing partisan loyalty, the early legal ethics scholars also criticized the moral neutrality of the lawyer-client relationship. The critiques of moral neutrality, however, like the critiques of partisan loyalty, were distorted by the assumption of morally corrupt cardboard clients who cared only about maximizing their wealth, freedom, or power over others. Because the early legal ethics scholars developed their ideal in a context defined by assumptions of moral lawyers and cardboard clients, they only considered clients who were by definition devoid of moral constraint. Additionally, the lawyers on which the ethicists focused were by definition more suited to moral decision-making than the cardboard clients the ethicists constructed. Focusing on client value actualization requires a type of moral neutrality on the part of the lawyer; because the lawyer focuses on the client's values, the lawyer must put her own values to the side. Although, the moral neutrality of client value-centered representation is not morally empty. Rather, it imports moral considerations into legal representation by drawing on the rich landscape of the client's values-including the client's moral values--that might otherwise be excised by the lawyer's focus on legal interests.

Not all outcomes of value clarification favor morality. Whether moral claims win out in the process of value clarification depends on how important moral

185. Markovits, supra note 68, at 273. The development of empathic understanding has long been a central component of the client-centered approach to interviewing and counseling. See BINDER ET AL., supra note 140, at $40-42$. Self-reflection also has been noted as a key component to successful communication between lawyers and clients. Bryant, supra note 143, at 49.

186. See generally Postema, Self-Image, in THE GOOD LAWYER, supra note 24.

187. See Charles J. Ogletree, Jr., Beyond Justifications: Seeking Motivations to Sustain Public Defenders, 106 HaRv. L. REv. 1239 (1993). 
values are to the person doing the clarifying. The process of value clarification will assist moral decision-making for persons who have internalized the moral values about the way they ought to treat others. The process also may assist persons who draw support for moral behavior from personal values, such as being an upstanding citizen or a good neighbor, in standing by their commitments, honoring their word, or maintaining their reputation in a community. Helping to clarify the values of a person with largely selfish values, however, is likely to assist that person in endorsing his own self-regarding behavior. The emotional core of Luban's moral activism is that standing by neutrally and allowing such a client to act on his selfish choices would be tantamount to condoning his mistreatment of others. Intervening to override the selfish choices of such a client might violate his autonomy and dignity, but it may at the same time be the only way to protect the autonomy and dignity of those who stand in harm's way.

The moral activist approach is defensible in the narrow circumstances toward which it was originally directed: the situation of a moral lawyer counseling a cardboard client. The moral activist solution, however, is ill-suited to the representation of three-dimensional clients because the tactics of moral activism run directly contrary to the principles of respect for a client's values. The moral activist lawyer's focus is on conforming the client's behavior to the lawyer's conception of the public good. To achieve this end, moral activist lawyers employ increasingly aggressive tactics of persuasion, coercion, and even betrayal, which deliberately distort the client's decision-making process. ${ }^{188}$ The further along the scale the lawyer goes, the more likely the lawyer is to be battling the client's deeply-held values. Less deeply-grounded resistance is likely to give way earlier in the process.

When lawyers and clients disagree about the morality of a course of action, the problems with moral activist counseling take on an added dimension. Like most people confronted with someone reluctant to act in accordance with what we see as the claims of morality, lawyers will have a tendency to believe that their clients are mistaken in their moral calculus. We can affirm on an intellectual level that our moral beliefs may reasonably differ from the moral beliefs of others. When we are confronted with someone who does not share our moral values, however, we struggle to understand their view as reasonable. We are more likely to believe

188. As Luban describes it,

moral activist client counseling may mean kindling the clients' consciences, but more often it will mean inventing alternative ways for clients to satisfy their interests. Sometimes it means persuading clients that the course of action they propose will harm them even when that is not necessarily so. In other instances, client counseling will require threatening to withdraw from a representation or refusing to follow a client's instructions. In the extreme cases, it means telling the client that if he does not back away from a course of action, the lawyer will blow the whistle on him.

Luban, Noblesse Oblige Tradition, supra note 92, at 737-38. 
that we are right and that the other person has made a "moral mistake." ${ }^{189}$ The belief that their clients are making a moral mistake will naturally tempt lawyers to intervene in their clients' decision-making, perhaps even by strong tactics, to prevent what the lawyers view as a moral wrong. The stakes for the lawyer of gaining a client's compliance with the claims of morality, as the lawyer sees them, are especially high. Lawyers do not simply sit by and tolerate their clients' differing moral viewpoints; they act on them. The force of the role disposition theorists' critique of the standard conception is that being forced to act against their own values is damaging to lawyers.

The kind of moral neutrality that results from respect for another person's values helps to discipline lawyers' tendency to impose their own moral and value choices on their clients in the guise of legal advice. If lawyers treat their clients as three-dimensional persons, lawyers' respect for the clients' values can help ensure the good that moral activism hopes to achieve by importing moral considerations into legal representation without succumbing to the danger of moral overreaching.

\section{BEYOND MORAL LAWYERS: THREE-DIMENSIONAL LAWYERS IN THE ARENA OF LEGAL REPRESENTATION}

In the role disposition critique discussed previously, ethicists concluded that lawyers were forced into the deeply dissatisfying kind of practice characterized by "zeal at the margin" by their partisan loyalty to clients who insisted that lawyers employ extreme tactics in the pursuit of immoral ends. If, however, the premise that lawyers construct their clients' objectives as legal interest maximization is true, it must follow that lawyers who practice "zeal at the margin" are at least partially responsible for their own misery. The possibility that lawyers actively shape their clients' objectives in the direction of legal interest maximization raises a puzzling question for the legal ethics scholars who raised a role disposition critique: why would lawyers willingly create situations that provide them with deep role dissatisfaction? Part of the answer must be that, just as clients are not solely motivated by the maximization of their legal interests, lawyers are not purely motivated by morality and a commitment to the public interest. Lawyers, like clients, are morally complex, three-dimensional persons who bring a mix of reputational interests, personal relationships, values, cares, and commitments into the arena of legal representation; all of these factors may affect lawyers' decision-making for better or for worse.

An examination of the moral complexity of lawyers is important for another reason as well. Even if the moral elitist premise that underlies the lawyerstatesman model-that lawyers are morally superior to their clients-is wrong, it may be true that lawyers are generally better situated than clients to make moral

189. Kruse, Moral Pluralism, supra note 109, at 402-07. 
decisions in the specific arena of legal representation. As discussed above, in the arena of legal representation, clients' own resolution of their conflicting wants, values, and interests may be distorted by temporary conditions of anger, fear, or insecurity. Because they are less personally and emotionally invested in the situations that lead to legal representation, lawyers are arguably better situated in legal representation to bring moral considerations to bear. To conclude that lawyers are better situated as moral decision-makers in the arena of legal representation, however, the ways in which lawyers' own wants, interests, and values compete with their moral and professional judgment should be considered.

First, and most obviously, the lawyer-client relationship involves a commercial exchange of services for fees, giving rise to an interest on the part of the lawyer in maximizing the financial return on a case. However if the lawyer gets paid-by the billable hour, contingent on the outcome, or on a flat fee or contract-the lawyer will have a financial interest in how the representation proceeds. Hourly fees give the lawyer an interest in spending a lot of time on a case, especially if the client is a "deep pocket" with virtually unlimited resources to sink into legal representation. Consequently, a lawyer billing by the hour may have a financial interest in making an extravagant investment of time or resources in a task that produces only marginally better results for the client. Contingent fees give lawyers an interest in maximizing outcomes with as little investment of time as possible, and at any cost to others along the way. Flat fees or contracts give lawyers an interest in resolving the representation of each client as quickly as possible, providing an incentive to conclude or to settle the matter whether or not the client has fully understood or bought into the terms of the settlement or agreement.

Moreover, lawyers have a legal interest in protecting themselves from malpractice lawsuits by advising clients to maximize legal interests and by leaving a clear paper trail anytime a client declines to follow that advice. Lawyers who fail to pursue a client's legal interests as far as possible risk exposure to malpractice claims if the client suffers financial damage as a result of the decision. Even if a client made an informed and reasonable decision not to pursue a possible avenue of relief, the lawyer may be concerned about liability in the event of the client's future change of heart. The commonly recommended "CYA" letters that lawyers send to clients are designed to protect themselves against future malpractice suits anytime a client decides to act against a lawyer's advice or the client's own interests. ${ }^{190}$

Lawyers also have reputational interests at stake in legal representation. Lawyers may depend on their professional reputations to make their practices run smoothly and may be subject to informal social sanctions for engaging in behavior that does not serve the values or interests of other members of their

190. See generally Karen Erger, Cover Me: Documentation Is More Than CYA, 98 LL. B.J. 316 (2008). 
professional community. ${ }^{191}$ In some cases, this pressure to conform to informal professional norms can support ethical behavior, ${ }^{192}$ but it also can work as a collective protectionist strategy to discriminate against lawyers who represent outsiders or who are themselves outsiders to the legal community. ${ }^{193}$

In addition, lawyers, like their clients, have personal values, cares, and commitments that come into play in legal representation. Their personal identities may be defined in part by their ability to win, their sense of fair play, or even their ruthlessness or gritty determination. They may have ambitions for career advancement, such as the desire to make partner in a firm or to get an appointment as a judge. Preserving relationships inside and outside of professional circles may be personally important to lawyers. They may have political commitments to practicing a certain kind of law or achieving a certain vision of social justice through their legal careers. They may value their families and the balance that they can achieve between work and home life. They may be members of religious communities or political organizations with accompanying values and commitments that interact with or affect the actions they take as lawyers. Any or all of these personal values and ambitions may affect lawyers' decisions in legal representation.

As other critics of the role disposition critique have noted, the premise that lawyers are driven to overly zealous tactics by the loyal pursuit of client interests does not paint a particularly accurate picture of legal practice. ${ }^{194}$ When lawyer behavior is examined more closely, a better explanation for why lawyers seem to engage in "zeal at the margin" is because their own interests are served by doing so, not because they are overly concerned with loyalty to their clients. Lawyers practicing in small communities are likely to curb the zeal of their advocacy to preserve their professional relationships and standing in the community. ${ }^{195}$ Lawyers for relatively powerless, one-shot clients are more than willing to manipulate their clients into taking deals that help maintain the lawyer's professional standing. ${ }^{196}$

Even in the places where the ruthless tactics of "zeal at the margin" seem to be a more accurate description of lawyers' practices, such as at large litigation firms, the lawyer's own drive to maximize profits by amassing billable hours provides at least as good an explanation as the premise that these lawyers are acting out of loyalty to their clients. At least, the assumption that big firm lawyers are driven by

191. See generally Wendel, supra note 97.

192. Id. at $1968-69$.

193. Id.

194. See Schneyer, Standard Misconception, supra note 24, at 1544-50; Stephen Ellmann, Lawyering for Justice in a Flawed Democracy, 90 Colum. L. Rev. 116, 124-29 (1990).

195. Schneyer, Standard Misconception, supra note 24, at 1546-47; Donald Landon, Clients, Colleagues, and Communities: The Shaping of Zealous Advocacy in County Law Practice, 1985 AM. B. Found. Res. J. 81.

196. Schneyer, Standard Misconception, supra note 24, at 1544-45 (discussing Abraham Blumberg, The Practice of Law as Confidence Game, 1 LAW \& Soc'Y REv. 15 (1967)). 
their own financial interests may better explain how the same lawyers who engage in scorched earth litigation tactics are also willing to gouge their own clients with questionable billing practices. ${ }^{197}$

In the arena of legal representation, lawyers and clients are thus differently situated as moral decision-makers, but it is difficult to conclude that one is better positioned than the other to keep legal representation within appropriate moral boundaries. The situations that lead clients to seek legal representation may incline clients to pursue their wants in favor of their values. Lawyers will generally have no particular investment in the situations in which their clients are embroiled. Lawyers, however, will inevitably have financial, reputational, and personal interests that present their own form of temptation to transgress moral and professional values. The principles of partisan loyalty and moral neutrality, redefined as attention and deference to client value choices, can help check lawyers' own self-interested motivations in legal representation.

\section{E. SPAULDING V. ZIMMERMAN IN THREE DIMENSIONS}

This Article began by suggesting that the traditional interpretation of Spaulding $v$. Zimmerman, the legal ethics classic in which the lawyer for a defendant in a personal injury automobile accident case chose not to inform the plaintiff that he suffered a life-threatening heart aneurysm, has been used by legal ethics scholars to raise the wrong question. As traditionally interpreted, Spaulding presents a moral and ethical dilemma for the lawyer: should the lawyer breach the professional duty of confidentiality to save a human life? ${ }^{198}$ This interpretation of Spaulding, however, is driven more by a theoretical interest in creating conflicts between role morality and ordinary morality than by the real-life facts of the case. This section returns to the real-life facts of Spaulding to explore the more interesting ethical question of why the lawyer felt entitled to settle the case without consulting John Zimmerman about whether to reveal the potentially life-saving information.

As argued above, at the heart of the more interesting question in Spaulding is the problem of legal objectification: the lawyer who pressed on to settlement without consulting his client about the moral issue of revealing Spaulding's life-threatening medical condition was thinking only in terms of his client's legal interests. Certainly, volunteering otherwise confidential information that could increase the amount Zimmerman owed in damages was contrary to his legal interests. The defense expert who examined Spaulding opined that the heart

197. See generally Lisa G. Lerman, Gross Profits?: Questions About Lawyer Billing Practices, 22 HofsTRA L. REv. 645 (1994); Lisa G. Lerman, Blue-Chip Bilking: Regulation of Billing and Expense Fraud By Lawyers, 12 Geo. J. Legal ETHICs 205 (1999); Susan Saab Fortney, The Billable Hours Derby: Empirical Data on the Problems and Pressure Points, 33 FordHAM URB. L.J. 171 (2005).

198. See, e.g., LUBAN, LAWYERS AND JUSTICE, supra note 34, at 149-50. 
aneurysm possibly was caused by the automobile accident at issue in the litigation. Furthermore, if the doctor was right, it might have affected the amount of money for which Spaulding was willing to settle the case; ${ }^{199}$ however, this narrow view of John Zimmerman's priorities overlooked his relationship with Spaulding and other values that might have influenced Zimmerman to reveal the medical information to save the life of his neighbor and friend.

If the lawyer had followed a client value-based approach to legal representation, a different situation would have resulted. First, the lawyer would not have received the information about Spaulding's heart aneurysm in the vacuum of legal interests. Because consistency with Zimmerman's long-term goals and deeply-held values would have been a central concern in the legal representation, the lawyer would have spent time at the beginning of the representation listening to Zimmerman about hearing about the context in which the lawsuit. When the information about Spaulding's heart aneurysm came across his desk, the lawyer would have been attuned to the importance of the information, not just to the legal case, but to Zimmerman's relationship with the Spaulding family. And, he would have flagged it as an important issue to discuss with his client.

In discussing with Zimmerman the question of whether to reveal the confidential information about Spaulding's medical condition, the lawyer would explain to Zimmerman that he wasn't legally required to reveal the information and that revealing it might drive up the costs of settlement, perhaps even over the limits of the insurance policy. The lawyer, however, would also be prepared to help Zimmerman put his legal interests into the context of his other values and commitments. For example, the lawyer might probe to ensure that whatever decision Zimmerman made about divulging the information was consistent with Zimmerman's long-term values, perhaps asking Zimmerman how he would feel looking back on the decision from some vantage point in the future.

From what we know about the real Spaulding case, the kind of discussion discussed above never occurred. Furthermore, Spaulding provides a window into the personal, financial, and reputational interests that may have prevented the discussion from occurring. Zimmerman's lawyer was hired and paid by the insurance company to represent Zimmerman, and the insurance contract most likely gave the insurance company rights to control the certain aspects of the defense. ${ }^{200}$ Although these contractual rights complicate the decision-making authority in the legal representation, they do not alleviate the lawyer's professional responsibility to consult with his client about important representation decisions, to share information that might create conflicting interests, and to

199. When the heart aneurysm was eventually discovered, it required corrective surgery that resulted in severe speech loss for David Spaulding. Cramton \& Knowles, supra note 7, at 71. Before it was corrected, David Spaulding suffered two years of intense and disabling chest pains. Floyd \& Gallagher, supra note 2, at 948.

200. Id. at 90-91; see also Floyd \& Gallagher, supra note 2, at 947. 
protect Zimmerman's interests in the event of a conflict of interest with the insurance company. ${ }^{201}$

The lawyer's own interest in future business with the insurance company provided a powerful incentive for him to overlook Zimmerman's actual objectives, which might have conflicted with the interests of the insurance company. Zimmerman was a one-shot client that the lawyer was not likely to encounter again. The lawyer's long-term financial and reputational interests lay in protecting his relationship with the insurance company that hired and paid him. ${ }^{202}$ If Zimmerman had insisted on revealing the confidential information, a settlement within the policy limits may not have been possible, creating a financial conflict of interest between Zimmerman and the insurance company. ${ }^{203}$ Even if the settlement remained within the policy limits, Zimmerman's insistence on revealing the information might have created a conflict of interest requiring the lawyer to withdraw. By construing Zimmerman's objectives narrowly in terms of legal interests the lawyer could maintain a view of his client's objectives in which his client's interests remained aligned with the interests of the insurance company: in a narrow sense, they shared an interest in minimizing the amount of the settlement.

Alternatively, the lawyer may have viewed the insurance company as the real party in interest and gave little thought to John Zimmerman as a client. ${ }^{204}$ Of course, that reasoning does not answer the question of why the lawyer did not engage in a serious value-based discussion about revealing confidential information with representatives of the insurance company. ${ }^{205}$ Possibly, if consulted, representatives of the insurance company would have directed the lawyer to reveal the information. After all, Spaulding's life hung in the balance, and a human life is a powerful counterweight to the profit motive of even the most calculating profit-maximizer. ${ }^{206}$ Even absent the long-term relationship with Spaulding that might have motivated Zimmerman to reveal the information, the

201. See Restatement (ThiRd) of LAW Governing Lawyers \$ 134 (2000); ABA Formal Op. 01-421 (Feb. $16,2001)$. For contrasting analyses of the difficulties of professional obligations in the insurance law context, see Thomas D. Morgan, What Insurance Scholars Should Know About Professional Responsibility, 4 ConN. INs. L.J. 1 (1997); Kent D. Syverud, What Professional Responsibility Scholars Should Know About Insurance, 4 CoNN. INS. L.J. 17 (1997).

202. Cramton \& Knowles, supra note 7, at 92-93.

203. Cf. ABA Comm. on Ethics and Prof'l Responsibility, Formal Op. $96-403$ (1996).

204. Cramton \& Knowles, supra note 7, at 93.

205. Id. at 93-94 (concluding that although it is possible that disclosure was discussed in the context of settlement offers with the insurance company "it is not clear ... that the issue was the subject of pointed and meaningful consultation" and that "[t]he most likely conclusion is that the defense lawyers made this decision largely on their own").

206. Id. at 94-95, quoting Stephen L. Pepper, Counseling at the Limits of the Law: An Exercise in the Jurisprudence and Ethics of Lawyering, 104 YALE L.J. 1545, 1606 (1995) ("I wonder why we assume that the middle-level manager in the defendant's insurance company . . . is likely to be more concerned with company profits (or with his own career advancement or security) than with the possible death of the plaintiff."); see also Floyd \& Gallagher, supra note 2, at 950 (noting that the trial attorneys sent a young associate to argue the case in 
lawyer might have assumed, at least presumptively, that the opportunity to save another human life was important to his insurance company client as well.

Finally, even after consultation, Zimmerman conceivably might have directed his lawyer not to reveal the information about Spaulding's health. Zimmerman might have decided that he could not harm his family by disclosing the information; the accident killed his brother and broke his father's neck, the family was struggling to hold things together, and he just could not inflict a devastating financial blow to his mother and surviving family members. If so, the lawyer taking a client-value based approach might have faced something like the dilemma discussed by early legal ethics scholars between whether to remain loyal to the duties of confidentiality or to follow the moral imperative to save a human life.

The lawyer's dilemma at the conclusion of a client value-based discussion, however, would not be the same dilemma envisioned by the early legal ethics scholars. The lawyer's dilemma would not arise out of the lawyer's solitary struggle over whether to break out of the impersonal demands of a professional role. Rather, the dilemma would arise in the context of overriding the decision of a three-dimensional client who had struggled through a difficult moral choice. Betraying another person with whom you stand in a relationship of trust and protection is qualitatively different than betraying a role obligation. Furthermore, this difference cannot help but affect the lens through which the lawyer views his ordinary moral obligations. The lawyer who chooses to override his client's considered moral decision says, in essence: "You may not be willing to bring more hardship upon your family to save David Spaulding's life, but I am going to do it anyway without your permission and against your wishes." When the early legal ethics scholars talked about breaking out of bureaucratic professional roles to acknowledge the human suffering of third parties, this kind of personal betrayal was not what they had in mind. ${ }^{207}$

Although it is difficult to say with any confidence what outcome would have resulted from a lawyer-client dialogue with either Spaulding or the insurance company, certainly a lawyer who felt a professional duty to shape the legal representation around the client's values as well as to protect the client's legal interests would not have been prevented by the logic of legal objectification and by the lawyer's self-interest that preempted the lawyer-client dialogue in the Spaulding case.

\section{Beyond Three-Dimensional Clients in Legal Ethics}

The previous Parts have argued that the problem of legal objectification poses

the Minnesota Supreme Court because they did not want to "face the justices and explain their behavior, having made no attempt to protect the boy").

207. See LUBAN, LAWYERS AND JUSTICE, supra note 34, at 127. 
a more central and important moral and ethical problem of legal professionalism than the conflicts between role morality and professional morality on which legal ethics historically focused. Further, these Parts have argued that a client value-based model of legal representation provides an antidote against both the self-seeking client behavior that legal interests-based counseling tends to promote and the danger of moral overreaching associated with the lawyerstatesman model. This Part examines legal representation in three contexts that challenge the client value-based ideal of representation proposed above: the representation of clients with diminished capacity, the representation of organizational clients, and cause lawyering. Each of the contexts examined in this Part poses a distinct problem in defining and ascertaining client objectives, both generally and in terms of client values. Implementing the methods of client value-based legal representation is neither simple nor straightforward in any of these contexts.

Even though it is not always easy to ascertain or define client objectives for clients with diminished capacity, organizational clients, or in cause lawyering, this Part argues that a client value-based approach to representation is still valuable as a professional ideal to guide the behavior of lawyers. Each context provides reasons, temptations, and opportunities for lawyers to revert to either purely legal interest-based representation or representation shaped around the lawyer's own values. A professional ideal that exhorts lawyers to shape representation around client values, even when the ideal is difficult to implement directly, provides a valuable check on lawyers' tendencies to either legally objectify their clients or impose their own values on the representation.

\section{A. REPRESENTING CLIENTS WITH DIMINISHED CAPACITY}

When lawyers represent children, the elderly, or other clients with diminished capacity, professional rules exhort them to "as far as reasonably possible, maintain a normal client-lawyer relationship with the client"; ${ }^{208}$ however, meeting this ideal is not always easy to achieve. Elderly, child, and developmentally disabled clients often lack the capacity to direct their lawyers. ${ }^{209}$ The very process of determining how much autonomy to allow such clients can result in "circular lawyer-centric thinking" in which the lawyer abides by the client's choices as long as the lawyer agrees with them and uses the client's disagreement about the client's interests as evidence that the client lacks competency to make an informed decision. ${ }^{210}$

208. MODEL RULES R. 1.14

209. See generally Paul R. Tremblay, On Persuasion and Paternalism: Lawyer Decisionmaking and the Questionably Competent Client, 1987 UTAH L. REv. 515.

210. Jean Koh Peters, The Roles and Content of Best Interests in Client-Directed Lawyering for Children in Child Protective Proceedings, 64 FordhaM L. REy. 1505, 1509 (1996). 
One possibility for a lawyer representing a client with diminished capacity is to act as a de facto guardian, shaping representation around what the lawyer determines to be in the client's best interests. ${ }^{211}$ The de facto guardian model, however, is criticized because it provides no constraints to check lawyer overreaching based on bias or conflicts of interest. ${ }^{212}$ The problem is that what is "best" for a child, elderly, or other impaired client often rests on a value judgment. Allowing these judgments to be made on the basis of the lawyer's values runs the risk of imposing lawyer values on clients whose own values diverge from that of the lawyer. Clients are thus exposed to decision-making based on the "the personalities, values and opinions of the randomly chosen lawyers" in their cases. ${ }^{213}$

Another possibility is for the lawyer to determine an impaired client's objectives by reference to the client's legal interests. ${ }^{214}$ Legal interests-based representation can help avoid the arbitrariness of "best interest" representation by grounding representation decisions in objectively determined legal rights. However, legal interests can be based on conflicting or substantively unfair law. ${ }^{215}$ Moreover, as with fully-functioning adult clients, the reduction of impaired clients to their legal interests results in a narrow and individualistic understanding of client objectives that overlooks significant non-legal reasons why clients might choose not to aggressively pursue their legal rights. ${ }^{216}$ As scholars writing about the role of lawyers for children have argued, the narrow focus on legal interests overlooks social relationships that child clients may value and can isolate them from caregivers and communities in which they form their strongest psychological and emotional bonds. ${ }^{217}$

The kind of client value-based approach to legal representation proposed in Part III of this Article is difficult to implement directly in the case of impaired clients. The methods of active listening and probing to determine whether a decision is consistent with a client's deeply-held values may be difficult or impossible to carry out with clients who are impaired in their "ability to understand, deliberate upon, and reach conclusions about matters affecting the client's own well-being." ${ }^{218}$ For example, elderly clients may not always be

211. Tremblay, supra note 209 , at 570 .

212. Id. at 575 .

213. Martin Guggenheim, A Paradigm for Determining the Role of Counsel for Children, 64 FoRDHAM L. REV. 1399, 1415 (1996).

214. Id. at 1412 (arguing that when representing an impaired child client, lawyers should be guided by the legal rights the law grants the child).

215. Annette R. Appell, Decontextualizing the Child Client: The Efficacy of the Attorney-Client Model for Very Young Children, 64 FORDHAM L. REv. 1955, 1962-65 (1996) (critiquing Guggenheim's legal interest representation proposal).

216. Tremblay, supra note 209 , at 551 .

217. See Annette R. Appell, Children's Voice and Justice: Lawyering for Children in the Twenty-First Century, 6 NEv. L.J. 692, 699 (2006).

218. Model Rules R. 1.14 cmt. 1 . 
lucid, or their decisions may reflect distorted priorities. ${ }^{219}$ Very young children may be unable to express their preferences, and even children who can express their opinions often lack the maturity and competence to direct their lawyers in complex decision-making. ${ }^{20}$

When invoked as a professional ideal rather than as a methodology, however, client value-based representation provides a concrete goal toward which lawyers representing diminished capacity clients can strive: to shape representation as much as possible around the unique values of the client. This goal is already articulated in the ethical rules governing representation of diminished capacity clients. For example, comments on Model Rule 1.14 on diminished capacity clients suggest that lawyers can check "the consistency of a [client's] decision with the known long-term commitments and values of the client."221

Similarly, scholars who have written thoughtfully about the nuances of maximizing client voice and direction in situations where the clients' decisionmaking ability is impaired have recognized methods that help lawyers approximate the client's unique values. For example, Paul Tremblay has suggested that with elderly clients, lawyers are encouraged to gather information about the client's long-term commitments and values by consulting family members who have "known and perhaps lived with the client for years."222 With children, the situation is different because children have "not yet reached the point in life when their values have been revealed." ${ }^{223}$ Jean Koh Peters has encouraged lawyers who represent child clients to view client competency as a "dimmer switch" that always allows access to some amount of information about the client's unique individuality and allows lawyers to stay true to the interests and wishes of child clients to whatever degree the child's individuality can be expressed. ${ }^{224}$

\section{B. REPRESENTING ORGANIZATIONAL CLIENTS}

Organizational clients present a different kind of challenge for a client value-centered approach to legal representation. Like most of legal ethics, the client-value-based approach is based on a paradigm of individual client representation. Only natural persons, however, have hopes, dreams, fears, loyalties, commitments, and values that fill out the dimensions of their objectives beyond simple legal interest maximization. The question in the organizational client context is how a lawyering model based on individual client representation can translate to situations where the client is not a natural person. More

219. See, e.g., Paul R. Tremblay, Counseling Clients Who Weren't Born Yesterday: Age and the Attorney-Client Relationship, 16 FAM. ADvoc. 24 (1993).

220. Guggenheim, supra note 213, at 1406-07.

221. MODEl RULES R. $1.14 \mathrm{cmt} .6$.

222. Tremblay, supra note 209 , at 569 .

223. Guggenheim, supra note 213 , at 1400 .

224. Id. 
particularly, the question arises whether a client value-based model makes any sense at all in the context of organizational clients.

In the legal ethics rules governing organizational representation, the individual client model serves as an imperfect metaphor for the representation of organizational clients. By ethical rule, lawyers for organizations are required to treat the organization itself, a fictitious entity, as the client. ${ }^{225}$ Taken literally, this means that the fictitious entity client must decide the objectives of the representation and engage in the consultation required about how those objectives will be pursued. ${ }^{226}$. Neither ethical standards nor lawyer training, however, provide direction on how a lawyer is to go about ascertaining the objectives of a fictitious entity "embodied in a large and diffuse collection of people and information."227 Lawyers are directed generally to defer to the decision-making of dulyauthorized constituents of the organization, usually officers and directors, on matters involving policy, operations, and the assessment of risk. ${ }^{228}$ Yet, most of the ethical heat in the representation of organizational clients is generated by situations in which the illegal actions of individual constituents, like managers, expose the organizational client to substantial injury. ${ }^{229}$ In such situations, lawyers are directed to protect the best interests of the organizational client, which brings the lawyer back to the difficult question of how to ascertain those interests.

Potentially, the easiest way for lawyers to figure out their organizational client's objectives, separating the interests of the organizational client from the self-interests of managers and other constituents, is to analyze the organization's objectives as completely congruent with the organization's legal interests. In individual client representation, such focus on a client's legal interests may divert lawyers away from a deeper understanding of a client's objectives. In the organizational context, by contrast, attention to the legal interests of the organization helps to focus lawyers on what is best for the organization rather than the individual constituents with whom the lawyers are more likely to interact and sympathize.

The premise that organizational clients are nothing more than the sum of their legal interests, however, is both too facile and somewhat suspect. The premise is too facile because organizations may well have objectives beyond the crude maximization of their freedom, wealth, and power over others. Organizations are complex entities with reputations, organizational cultures, relationships with outsiders, and ties with the community that create interests beyond the

225. Model Rules R. 1.13(a).

226. See MODEL RULES R. 1.2(a) ("[A] lawyer shall abide by a client's decisions concerning the objectives of representation and ... shall consult with the client as to the means by which they are to be pursued.").

227. See Donald Langevoort, The Epistemology of Corporate Securities Lawyering: Beliefs, Biases and Organizational Behavior, 63 BROOK. L. REv. 629, 631 (1997).

228. MODEl RULES R. $1.13 \mathrm{cmt} .3$.

229. MOdEl RULES R. 1.13(b). 
maximization of their profits. ${ }^{230}$ The argument is also suspect because it too easily conflates the objectives of organizational clients with the profit motive of the lawyers who represent them. Lawyers whose financial success depends on billable hours have self-interested reasons to pursue every conceivable legal argument at their client's expense. ${ }^{231}$ Lawyers' legal objectification of organizational clients may thus provide a convenient rationalization for the pursuit of the lawyer's own interests under the guise of zealous representation of client interests.

Alternatively, it may be tempting to posit the lawyer-statesman model as a more promising ideal for guiding lawyers' professional role in the organizational client representation context. Responsible corporate decision-making that takes the organization's broader interests into account requires a range of viewpoints from both insiders who are assimilated into corporate culture and outsiders who can challenge it. ${ }^{232}$ Within this mix of views, lawyers can play the role of the corporate conscience, questioning whether and how the proposed actions of the organization comport with the public interest. ${ }^{233}$ Further, the more intrusive methods of moral activist counseling do not present the same dangers of moral overreaching in the corporate context as they do in the individual client context, because in the corporate context, lawyers operate as one voice among many in the organizational decision-making process. ${ }^{234}$

Even if it is less troubling in the organizational client context, the lawyerstatesman model poses problems of implementation in the corporate context. Because corporate clients are more powerful and demand greater deference, the lawyer may feel less comfortable raising explicitly moral considerations as part of legal representation. ${ }^{235}$ As a result, corporate lawyers may be less likely to

230. Joanne Martin, Organizational Culture: Mapping the Terrain 93-115 (2002) (discussing the use of different perspectives on defining corporate culture to recognize these diverse constituencies and interests).

231. See Abram Chayes \& Antonia H. Chayes, Corporate Counsel and the Elite Law Firm, 37 STAN. L. REv. 277, 296-97 (1985); see also Robert Gordon, The Ethical World of Large-Firm Litigators: Preliminary Observations, 67 FORDHAM L. REv. 709, 716-18, 725-26 (1998) (noting a disjuncture between large-firm litigators' view that clients want aggressive no-holds-barred representation and in-house counsels' view that clients want cost-efficiency).

232. See generally Donald Langevoort, The Human Nature of Corporate Boards: Law, Norms, and the Unintended Consequences of Independence and Accountability, 89 GEO. L.J. 797 (2001).

233. Stephen Pepper, Lawyers' Ethics, supra note 105, at 194-95 (1999); Russell G. Pearce, The Legal Profession as a Blue State: Reflections on Public Philosophy, Jurisprudence, and Legal Ethics, 75 FORDHAM L. REV. 1339, 1364-65 (2006).

234. Pepper, Lawyers' Ethics, supra note 105, at 194; see also LuBAN, Human Dignify, supra note 167, at 87 (arguing for an abolishment of the lawyer-client privilege for corporations because corporations do not have human dignity to violate by self-incriminatory disclosure).

235. Pepper, Lawyers' Ethics, supra note 105, at 194-95; Gordon, supra note 231, at 711; Mark Suchman, Working Without a Net: The Sociology of Legal Ethics in Corporate Litigation, 67 FordHAM L. Rev. 837, 843-44 (1998); see also LUBAN, Human Dignity, supra note 167, at 87 (acknowledging that his argument for abolishing the attorney-client privilege in the corporate context-though strong philosophically-has been viewed as "too fanciful to take seriously"). 
engage in an explicitly moral dialogue with their clients based on the concern that their "own view of morality" is not universally shared. ${ }^{236}$

Client value-based representation presents an alternative for lawyers representing organizational clients that lies somewhere between the crude assumptions of legal interest maximization and concerns with what may seem the overly moralistic approach of the lawyer-statesman model. As apparent in the individual representation context, part of the purpose of client value clarification is to curb impulsive client decision-making that may be distorted by anger, fear, or insecurity and to ensure that legal representation furthers the client's deeper and more fundamental values. ${ }^{237}$ Lawyers in the corporate context can serve a similar function of checking the sometimes unrealistic optimism that tends to pervade business and corporate culture by raising pragmatic concerns based on measured and risk-averse assessments about the long-term consequences of proposed decisions. ${ }^{238}$ Additionally, lawyers can help promote and invite their organizational clients' voluntary compliance with legal regulation by being spokespersons with corporate management about the purposes and functions of legal regulations. ${ }^{239}$ Rather than attempting a moral lecture, such pragmatic inquiries and purposive explanations of the law invite the constituents with organizational decision-making authority to consider the long-term goals and values of the organization and to consider how the goals and values of the organization fit within the structure of the legal regulations that govern corporate activity.

Empirical analysis of the attitudes and reported behavior of corporate lawyers suggests that these lawyers often engage in some of the same counseling techniques designed in the individual client context to probe the consistency of an organizational client's decision with the client's deeper values. ${ }^{240}$ For example, researchers in one study concluded that when counseling their business clients, lawyers tend to couch moral considerations in pragmatic or reputational

236. In the words of one large-firm litigator, explaining why he would not engage his client in a moral dialogue: "I personally would have a problem conveying my own view of the morality of the situation to a client. I think morality is a very slippery concept, primarily in the eye of the beholder." Robert L. Nelson, The Discovery Process as a Circle of Blame: Institutional, Professional, and Socio-Economic Factors That Contribute to Unreasonable, Inefficient, and Amoral Behavior in Corporate Litigation, 67 FORDHAM L. REv. 773, 780 (1998).

237. See supra Part III.B.

238. Langevoort, Epistemology, supra note 227, at 49; Suchman, supra note 235, at 844 (lawyers tend to assume that unethical behavior will carry long-term negative consequences).

239. See generally Donald C. Langevoort, Someplace Between Philosophy and Economics: Legitimacy and Good Corporate Lawyering, 75 FORDHAM L. REv. 1615 (2006).

240. The empirical study to which this section refers—called Ethics: Beyond the Rules-was sponsored by the ABA Section on Litigation, and invited a team of legal scholars, legal ethics scholars, social scientists to study large firm litigators. Robert E. Nelson, et al., Introduction: Bringing Legal Realism to the Study of Ethics and Professionalism, 67 FordHAM L. REv. 697, 701 (1998). The team interviewed both partners and associates at large law firms in two cities over extended weekends. Id. A year later, they interviewed groups of judges, plaintiffs' counsel, and in-house counsel in the same two cities. Id. at 702. The results were published in a series of articles in the Fordham Law Review. 
concerns, such as asking a client what a proposed course of action would look like on the front page of the newspaper or how it would be viewed by a judge or the jury. ${ }^{241}$ Such appeals to reputation are not simply part of a pragmatic cost-benefit analysis or strategy for making the lawyer's moral judgment of the client more palatable. Rather, as Mark Suchman points out, "[t]he 'newspaper test' operates much like Mead's 'generalized other'-providing a social lookingglass that allows one ... to see and judge oneself."

\section{CAUSE LAWYERING}

Finally, the representation of politically vulnerable, socially disadvantaged, and otherwise disempowered clients presents unique challenges to a client value-based representation, because it poses a special case of the tension between legal interests-based representation and the dangers of moral overreaching associated with the lawyer-statesman ideal.

In the view of some commentators, the representation of politically and socially disempowered clients presents the most appropriate venue for a client value-based approach to legal representation. Because of their relative lack of legal sophistication, such clients are seen as particularly vulnerable to domination by their lawyers. ${ }^{243}$ Moreover, the construction of client objectives in purely legal terms in the poverty law context is especially pernicious because it reinforces inequities built into the law itself. Because those without social advantage lack the power to influence the law-making process, the law that affects their lives is often created without taking their perspectives into account. A client value-based approach to legal representation holds out the promise of making law more responsive to the lived experience of clients by shaping legal representation around the values and narratives of clients. ${ }^{244}$

The conditions of poverty law practice, however, pressure poverty lawyers in the direction of legal interest-based representation. The overwhelming need for legal services and the relentless demands to meet the immediate and often desperate needs of individual clients create pressures to process cases routinely and to settle them as quickly as possible. ${ }^{245}$ To access the remedies that law offers politically vulnerable or socially disadvantaged clients, lawyers must force their clients' stories into narratives that may be disconnected from the perspectives and

241. Gordon, supra note 231 , at 733 ; Suchman, supra note 235 , at $844-45$.

242. Id.

243. See O'Leary, supra note 147, at 107; Pepper, Lawyers' Ethics, supra note 105, at 194-95.

244. Anthony Alfieri, Reconstructive Poverty Law Practice: Learning the Lessons of Client Narrative, 100 YALE L.J. 2107, 2131-33 (1991); White, Sunday Shoes, supra note 177, at 50-51.

245. See generally Gary Bellow, Turning Solutions Into Problems: The Legal Aid Experience, 34 NAT'L LEGAL AID \& DEFENDER ASS'N BRIEFCASE 106 (1977). 
circumstances of their clients' lives. ${ }^{246}$ Furthermore, the pressure to meet the unmet legal needs of individuals in poverty works against the ability of poverty lawyers to use individual client representation to change the contours of the law. The incentive for more powerful repeat players, like landlords, employers, and banks, is to settle cases that might make unfavorable law, while the incentives for one-shot individual clients are to maximize their tangible gain in the particular case by taking the deals that they are offered. ${ }^{247}$

Moreover, the typical client value-based methods of overcoming legal interest-based representation through active listening and probing for client values are arguably insufficient to overcome the barriers created by social subordination. Even when poverty lawyers attempt to attend more holistically to the values of fewer individual clients, such as in law school clinic settings, the individual focus of representation in discrete cases has a tendency to isolate the client's objectives from the collective and community values required for reform of unjust laws and systems. ${ }^{248}$ In addition, clients who seek legal services are often in crisis situations of eviction from housing, denial of benefits for life necessities, loss of parental rights, or deportation. Attention to the unique needs of such individual clients will often be synonymous with getting whatever remedy the law offers to alleviate the crisis.

To escape the endless grind of remedying injustice one client at a time, lawyers for politically and socially disadvantaged clients engage in what Stuart Scheingold and Austin Sarat call "cause lawyering." representation of individual clients is a means to the achievement of political ends that transcend the individual clients' financial or legal interests. ${ }^{250}$ Cause lawyers choose or recruit clients to fit the needs of the cause and put the needs of the cause over the needs of the individual clients who represent the class for whom the lawyers advocate. ${ }^{251}$ Although the needs of individuals are subordinated to collective goals, the promise of cause lawyering is to effect reforms that will improve conditions for entire classes of persons affected by injustice embedded in the law itself. ${ }^{252}$

Cause lawyers are arguably a special embodiment of the lawyer-statesman

246. See Alfieri, Client Narrative, supra note 244, at 2112-13; White, Sunday Shoes, supra note 177, at 27-29.

247. Marc Galanter, The Duty Not To Deliver Legal Services, 30 U. MIAMI L. REv. 929, 938-40 (1976).

248. Sameer Ashar, Law Clinics and Collective Mobilization, 14 ClinICAL L. Rev. 355, 357-58 (2008); see also William H. Simon, Homo-Psychologicus: Notes on a New Legal Formalism, 32 StAN. L. Rev. 487, 496-505 (1980).

249. See Stuart A. Scheingold \& Austin Sarat, Something to Believe In: Polmtics, Professionalism and CaUse LaWyering (2006).

250. Id. at 6-7.

251. LUBAN, LAWYERS AND JUSTICE, supra note 34, at 317.

252. Lucie E. White, Mobilization on the Margins of the Lawsuit: Making Space for Clients to Speak, 16 N.Y.U. REv. L. \& Soc. Change 535, 535-37 (1987-88). 
ideal. ${ }^{253}$ The relative independence from client control and the ability to define and pursue public interest goals directly are consonant with the ideal of the lawyer who mediates between the client's interests and the public good. As Scheingold and Sarat state it, cause lawyers are "advocates not only, or primarily, for their clients but for causes and, one might say, for their own beliefs."254

The dangers of moral overreaching associated with the lawyer-statesman ideal, however, also assert themselves in the context of cause lawyering. Perhaps the quintessential example of cause lawyering is the NAACP's campaign to desegregate public schools. ${ }^{255}$ This campaign involved both a carefullyorchestrated legal challenge that resulted in the historic 1954 ruling in Brown v. Board of Education ${ }^{256}$ and a persistent decades-long effort to enforce and implement Brown through litigation in lower federal courts. ${ }^{257}$ As Derrick Bell argued in one of the earliest critiques of Civil Rights lawyering, however, the lawyers' pursuit of the goal of desegregated schools became disconnected from the goal of better quality education that desegregation was designed to achieve. ${ }^{258}$ Committed to the symbolic importance of desegregation, beholden to their middleclass donors, and disconnected from the experience of inner-city black families, national-level NAACP lawyers opposed local efforts by community groups and parents to structure settlements that would retain segregated school systems and require the investment of resources to improve the quality of inner-city schools. ${ }^{259}$

In the context of cause lawyering, a client value-based model of representation presents itself not so much as a method of representing individual clients, but as a professional ideal or "theory of practice" around which lawyers representing socially and politically disadvantaged clients can strive to shape their representation. ${ }^{260}$ The strategies of a new generation of lawyers practicing law for socially and politically disadvantaged clients seek greater participation from clients in the formation of collective goals, while at the same time recognizing that the clients' capacity for voicing collective values may have to be consciously created, rather than merely received. ${ }^{261}$ Lucie White, for example, recounts ways to create space

253. See, e.g., LUBAN, LAWYERS AND JUSTICE, supra note 34, at 237-38 (connecting the Brandeis vision of the "people's lawyer" with public interest law practice); see also SCHEINGOLD \& SARAT, supra note 249, at 9-17 (exploring the continuities and discontinuities of cause lawyering and the lawyer-statesman ideal).

254. Id. at 9 .

255. Austin Sarat \& Stuart Scheingold, What Cause Lawyers Do For, and To, Social Movements: An Introduction, in CAUSE LAWYers AND Social MOVEMENTS 1, 4-7 (Sarat \& Scheingold eds., 2006).

256. Brown v. Board of Educ. of Topeka, 347 U.S. 483 (1954).

257. Derrick A. Bell, Jr., Serving Two Masters: Integration Ideals and Client Interests in School Desegregation Litigation, 85 YALE L.J. 470, 472-82 (1976).

258. Id. at 487-88.

259. Id. at $487-93$.

260. Ascanio Piomelli, Appreciating Collaborative Lawyering, 6 CLINICAL L. REv. 427, 429-31 (2000).

261. For example, see generally Gerald LOPEZ, Rebellious LAWYeRING: ONE ChICANo's VISION OF Progressive Law Practice (1992); Anthony V. Alfieri, The Antinomies of Poverty Law and a Theory of Dialogic Empowerment, 16 N.Y.U. Rev. L. \& Soc. ChANGE 659 (1987-88). 
in the "margins" of a lawsuit for class members to discover and define a collective voice through speak-out events or street theater. ${ }^{262}$ Lawyers also have formed alliances with community organizing groups, often playing a subordinate role in the definition of the legal services that would benefit the larger social movement. ${ }^{263}$ These strategies seek to avoid the disengagement from client values that may result when the lawyer defines the "public interest" in isolation from the values and perspectives of the clients. ${ }^{264}$

\section{CONCLUSION}

The debates in theoretical legal ethics center around the way lawyers' roles should be conceived, and they both arise from and help define the way lawyers practice law. The early legal ethics scholars sought a definition of lawyers' professional "role morality" that would serve the theoretical purpose of generating conflicts between role morality and ordinary morality; however, in starting from the standpoint of theory, this Article argues, they misinterpreted practice. The lawyer behavior that looked to them like the overindulgence of client interests was really a different phenomenon. The behavior was really the lawyers' own legal objectification of their clients: the narrow construction of client objectives in terms of legal interests and disengagement from client values. As a result of misdiagnosing the problems that plagued legal professionalism, legal ethics scholars proposed a solution, the "lawyer-statesman" model, which aggravates the problem of lawyer disengagement from client values by encouraging lawyers to shape legal representation around the lawyer's conception of morality and the public interest.

The client value-based approach to representation that this Article proposes asserts a faith in client values as a corrective force for both the anti-social aspects of legal interest maximization and the hubris of the lawyer-statesman ideal. Attention to client values may not, in the end, provide salvation from the competitive and self-interested culture of American society. If, however, competition and self-interest are culturally pervasive, reliance on lawyers to transcend this cultural tendency by appealing to their own personal values is just as idealistic a dream. The goal of shaping representation around the values of clients provides an opportunity for legal representation to redeem itself without compromising the core values of client loyalty and service that lie at the heart of legal professionalism. Before the legal community abandons the professional values of client loyalty and service, lawyers should attempt to actually represent their clients, rather than zealously pursue their clients' legal interests.

262. White, Mobilization at the Margins, supra note 252.

263. See generally CAUSE LAWYERS AND SOClAL MOVEMENTS, supra note 255.

264. See generally Lucie E. White, Collaborative Lawyering in the Field? On Mapping the Paths from Rhetoric to Practice, 1 Clinical L. REv. 157 (1994). 